\title{
Synthetic Approaches Towards Tubulysins and Derivatives Thereof
}

\author{
Uli Kazmaier*, Angelika Ullrich and Judith Hoffmann
}

Institute of Organic Chemistry, Saarland University, 66041 Saarbrücken, Germany

\begin{abstract}
Tubulysins, linear tetrapeptides produced by several strains of myxobacteria, show an extremely high toxicity towards a wide range of cancer cell lines, with $\mathrm{IC}_{50}$ values in the nano or even picomolar range. Therefore, tubulysins and their derivatives might be suitable candidates for the development of antitumor drugs. Several synthetic approaches for tubulysins and derivates have been developed, which will be discussed in the review.
\end{abstract}

Keywords: Antitumor drugs, myxobacteria, peptides, tubulin, tubulysin.

\section{INTRODUCTION}

The tubulysins are a family of tetrapeptides produced by several strains of myxobacteria in rather small quantities $(<4$ $\mathrm{mg} / \mathrm{l}$ culture broth). In 2000, Reichenbach and Höfle described the isolation of the first members of this family from the myxobacterial strains Archangium gephyra and Angiococcus disciformis [1]. The tubulysins showed no activity against bacteria and only little against fungi, but with $\mathrm{IC}_{50}$ in the picomolar range, they reveal extremely high cytotoxicity towards tumor cell lines. Several more tubulysins (Fig. 1) have been described in 2004 and their structure in crystal and solution has been determined [2].

At the $N$-terminus an unusual $N$-methyl- $(R)$-pipecolic acid (Mep) is found, connected to the only proteinogenic amino acid L-isoleucine. A highly exotic building block is located in the middle of the molecule, called tubuvaline (Tuv). Biosynthetically, this building block is generated from valine via $\mathrm{N}$-methylation, $\mathrm{C}_{2}$-chain elongation, coupling to cysteine and subsequent heterocyclization/oxidation to form the thiazole moiety $[3,4]$.

The acetoxy group and the highly unusual acylal side chains are biosynthetically introduced later on via oxidation of the $N$-methyl group and the $\alpha$-position at the thiazole ring, followed by acylations. The different tubulysins mainly differ in the acylal side chain $\left(\mathrm{R}^{1}\right)$. A second difference is found in the $C$-terminal, also $\mathrm{C}_{2}$-prolonged, amino acid, called tubuphenylalanine (Tup) or tubutyrosine (Tut), depending on the original amino acid incorporated. Recent biosynthetic studies by Müller et al. using a third producing strain Cystobacter sp. SBCbO04 and a mutant of Angiococcus disciformis (An d48) resulted in the identification of a wide range of tubulysin derivatives, mainly biosynthetic intermediates (Fig. 2) [5].

In some examples the final stages of the proposed biosynthesis, the oxidation/acylation, are (in part) missing, others result from an abortive biosynthetic pathway. For

*Address correspondence to this author at the Institute of Organic Chemistry, Saarland University, Bldg. C4.2, 66123 Saarbruecken, Germany; Tel: +0049681302 3409; Fax: +0049681302 2409;

E-mail: u.kazmaier@mx.uni-saarland.de example, in tubulysin $\mathrm{U}$ the $N$-methylation at the Tuv-unit is deleted, suppressing the incorporation of the acylal side chain. Pretubulysin was found to be the first enzyme-free intermediate in the pathway [5].

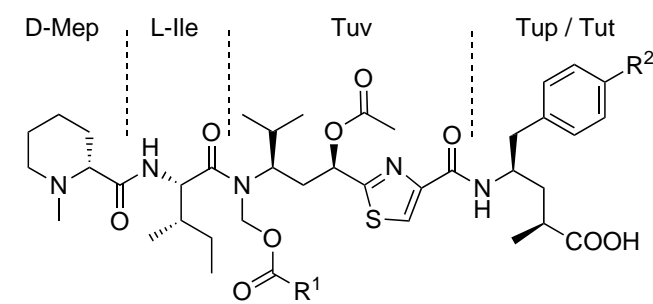

Mep: N-Methylpipecolic acid

Tuv: Tubuvaline

Tup: Tubuphenylalanine $\left(\mathrm{R}^{2}=\mathrm{H}\right)$

Tut: Tubutyrosine $\left(\mathrm{R}^{2}=\mathrm{OH}\right)$

\begin{tabular}{|c|c|c|}
\hline Tubulysin & $\mathrm{R}^{1}$ & $\mathrm{R}^{2}$ \\
\hline A & $\mathrm{CH}_{2} \mathrm{CH}\left(\mathrm{CH}_{3}\right)_{2}$ & $\mathrm{OH}$ \\
\hline B & $\mathrm{CH}_{2} \mathrm{CH}_{2} \mathrm{CH}_{3}$ & $\mathrm{OH}$ \\
\hline C & $\mathrm{CH}_{2} \mathrm{CH}_{3}$ & $\mathrm{OH}$ \\
\hline D & $\mathrm{CH}_{2} \mathrm{CH}\left(\mathrm{CH}_{3}\right)_{2}$ & $\mathrm{H}$ \\
\hline E & $\mathrm{CH}_{2} \mathrm{CH}_{2} \mathrm{CH}_{3}$ & $\mathrm{H}$ \\
\hline $\mathbf{F}$ & $\mathrm{CH}_{2} \mathrm{CH}_{3}$ & $\mathrm{H}$ \\
\hline G & $\mathrm{CH}=\mathrm{C}\left(\mathrm{CH}_{3}\right)_{2}$ & $\mathrm{OH}$ \\
\hline H & $\mathrm{CH}_{3}$ & $\mathrm{H}$ \\
\hline I & $\mathrm{CH}_{3}$ & $\mathrm{OH}$ \\
\hline
\end{tabular}

Fig. (1). Structures of the tubulysins.

The high cytotoxic activity of the tubulysins results from their ability to bind to tubulin [6], disturbing the microtubule skeleton in the dividing cell, thus inducing apoptosis. This turns out the tubulysins into ideal candidates for the development of anti cancer drugs [7-9], as long as it is possible to target the tumor cells selectively [10]. Therefore, folic acid conjugates have been prepared, because high-affinity folate receptors (FR) are highly expressed on a wide range of human cancer cells. This approach allows to selectively address cancer cells in the presence of normal tissue cells [11,12]. Alternatively, the tubulysins can also be bound to dendrimers [13] or cyclodextrine-based nanoparticles, showing higher in vivo activity compared to the corresponding tubulysins alone [14]. Interestingly, also pretubulysin, the precursor of the tubulysins, shows a very high cytotoxicity towards a wide range of tumor cell lines $[15,16]$. With respect, that this compound is much easier synthetically available, and it 
<smiles>CCCC(=O)OCN(C(=O)[C@@H](NC(=O)[C@@H]1CCCCN1C)[C@@H](C)CC)[C@@H](C[C@@H](O)c1nc(C(=O)N[C@@H](Cc2ccccc2)C[C@@H](C)C(=O)O)cs1)C(C)C</smiles><smiles>CC[C@H](C)[C@H](NC(=O)[C@@H]1CCCCN1C)C(=O)N(COC(=O)CC(C)C)[C@H](C[C@@H](O)c1nc(C(=O)N[C@@H](Cc2ccccc2)C[C@@H](C)C(=O)O)cs1)C(C)C</smiles><smiles>CC[C@H](C)[C@H](NC(=O)[C@@H]1CCCCN1C)C(=O)N(CO)[C@@H](CCc1nc(C(=O)N[C@@H](Cc2ccccc2)C[C@@H](C)C(=O)O)cs1)C(C)C</smiles><smiles>CC[C@H](C)[C@H](NC(=O)[C@@H]1CCCCN1C)C(=O)N(CO)[C@H](C(=O)Cc1nc(C(=O)N[C@@H](Cc2ccccc2)C[C@@H](C)C(=O)O)cs1)C(C)C</smiles><smiles>CC[C@H](C)[C@H](NC(=O)[C@@H]1CCCCN1C)C(=O)N[C@H](C(=O)Cc1nc(C(=O)N[C@@H](Cc2ccccc2)C[C@@H](C)C(=O)O)cs1)C(C)C</smiles><smiles>CC[C@H](C)[C@H](NC(=O)[C@@H]1CCCCN1C)C(=O)N[C@H](C(=O)[C@H](O)c1nc(C(=O)N[C@@H](Cc2ccccc2)C[C@@H](C)C(=O)O)cs1)C(C)C</smiles><smiles>CC[C@H](C)[C@H](NC(=O)[C@@H]1CCCCN1C)C(=O)N[C@@H](CCc1nc(C(=O)N[C@@H](Cc2ccccc2)C[C@@H](C)C(=O)O)cs1)C(C)C</smiles><smiles>CC[C@H](C)[C@H](NC(=O)[C@@H]1CCCCN1C)C(=O)N[C@H](C(C)C)C(O)Cc1nc(C(=O)N[C@@H](Cc2ccccc2)C[C@@H](C)C(=O)O)cs1</smiles><smiles>CC[C@H](C)[C@H](NC(=O)[C@@H]1CCCCN1C)C(=O)N(C)[C@H](CCc1nc(C(=O)N[C@@H](Cc2ccccc2)C(=O)O)cs1)C(C)C</smiles><smiles>CC[C@H](C)[C@H](NC(=O)[C@@H]1CCCCN1C)C(=O)N[C@H](C[C@@H](OC(=O)C(C)C)c1nc(C(=O)N[C@@H](Cc2ccccc2)CC(C)C(=O)O)cs1)C(C)C</smiles><smiles>CC[C@H](C)[C@H](NC(=O)[C@@H]1CCCCN1C)C(=O)N(C)[C@H](CCc1nc(C(=O)N[C@@H](Cc2ccccc2)CC(C)C(=O)O)cs1)C(C)C</smiles>

Fig. (2). New tubulysin derivatives isolated from Angiococcus disciformis An d48.

lacks labile structures, such as the acylal side chain and the acetoxy group, it is an ideal candidate for drug development as well [17]. For example, pretubulysin also shows a strong anti-angiogenic effect, both in vitro and in vivo [18]. As indicated by photoaffinity labeling experiments, pretubulysin binds to tubulin as the parent component [19]. In contrast to pretubulysin, containing an $\mathrm{N}$-methyl group at the central amino acid, other derivatives such as tubulysin $\mathrm{U}$ and $\mathrm{V}$, missing this $N$-alkyl substituent, are significantly less potent [20-22]. A wide range of other tubulysin derivatives has been prepared and investigated for their biological activity [23-25]. This review will focus on the synthetic strategies developed for the synthesis of tubulysins and simplified derivatives thereof. Stereoselective syntheses of the different building blocks will be discussed in chronic order, as well as the syntheses of the final compounds.

\section{SYNTHESIS OF TUBUVALINE AND ITS DERIVA- TIVES}

The first synthesis of the tubuvaline fragment was described by Höfle and Reichenbach in a patent in 2001 (Scheme 1) [26]. Starting from protected $(S)$-valinol (1), oxidation and subsequent Wittig reaction with the ylide derived from 2 afforded the thiazolyl enol ether 3, which was hydrolyzed towards the corresponding ketone 4 . Reduction with $\mathrm{NaBH}_{4}$ gave rise to the secondary alcohol $\mathbf{5}$ as a diastereomeric mixture. For the incorporation of the side chain, the ethyl ester was converted into the selectively cleavable trimethylsilylethyl ester, before the side chain was introduced via alkylation of the Cbz-amide. Subsequent cleavage of the silyl ester provided the required building block 6 . 
<smiles>CC(C)[C@H](CO)NC(=O)[O-]</smiles><smiles>CCOC(=O)c1csc(/C(=C/C(NC(=O)OC)C(C)C)C(C)C)n1</smiles><smiles>CCOC(=O)c1csc(C(=O)CC(NC(=O)OCc2ccccc2)C(C)C)n1</smiles><smiles>CCOC(=O)c1csc([C@@H](O)CC(NC(=O)OCc2ccccc2)C(C)C)n1</smiles><smiles>[R]C(=O)OCN(C(=O)O)C(CC(=O)c1nc(C(=O)O)cs1)C(C)C</smiles>

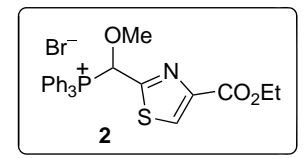

Scheme 1. Synthesis of Tuv fragment according to Höfle et al:: a) Swern oxidation; b) $\mathrm{DBU}, 2$; c) $\mathrm{THF}, \mathrm{HCl}(35 \%)$; d) $\mathrm{EtOH}$, $\mathrm{NaBH}_{4}$; e) $\mathrm{NaOH}$; f) TMSEtOH, DCC; g) $\mathrm{NaH}, \mathrm{R}^{1} \mathrm{CO}_{2} \mathrm{CH}_{2} \mathrm{Cl} ; \mathbf{h}$ ) TBAF.

In 2004, also in patents, Dömling et al. described a straightforward synthesis of an $\mathrm{N}$-protected tubuvalineprecursor based on a modified Passerini protocol (Scheme 2) $[27,28]$. This approach was used in the synthesis of tubuvaline $\mathrm{U}$ and $\mathrm{V}$ as well $[29,30]$. In this case Schöllkopf isocyanide (9), accessible in one step from glycine isocyanide [31], reacting with Boc-protected homovaline aldehyde (7) and thioacetic acid (8) as an acid component. The $\alpha$-acetoxysubstituted tubuvaline derivative $\mathbf{1 0}$ was obtained as a 3:1 diastereomeric mixture, albeit in moderate yield. The major diastereomer was found to be the required one. Subsequent saponification of the thiazole ester resulted in the simultaneous cleavage of the acetate group (11).

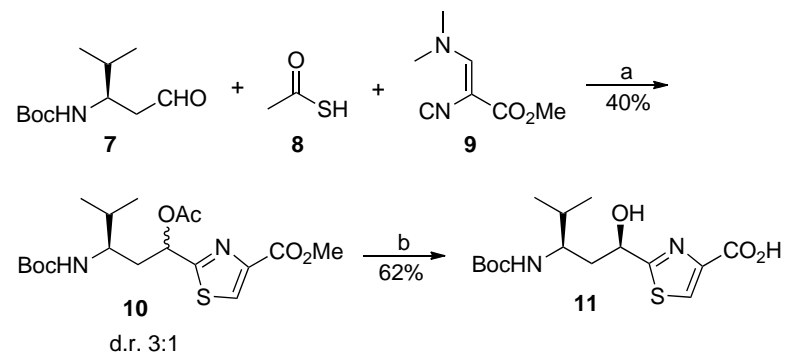

Scheme 2. Synthesis of Tuv fragment according to Dömling et al: a) $1 . \mathrm{BF}_{3} \cdot \mathrm{Et}_{2} \mathrm{O}, 7, \mathrm{THF},-78^{\circ} \mathrm{C} ; 2$. simultaneous addition of 8 and 9 in THF by syringe pump over $30 \mathrm{~min}$; then room temperature overnight, major isomer separated; b) $\mathrm{NaOH}, \mathrm{THF} / \mathrm{H}_{2} \mathrm{O}(3: 1)$.

During their studies towards the synthesis of the Tuv-Tup dipeptide fragment, Wipf et al. developed an interesting approach using an asymmetric hydroxylation to introduce the $\alpha$-hydroxy functionality (Scheme 3) [32]. Starting from $N$ protected valinol 1, TEMPO oxidation and subsequent Wittig reaction provided $\alpha, \beta$-unsaturated ester 12. This building block is also available directly from Cbz-valine methyl ester according to Knaus et al. [33]. Catalytic hydrogenation of 12 has been found to be not a trivial issue because of undesired $\gamma$-lactam formation. Finally, the double bond could be re- moved via $\mathrm{Cu}$-catalyzed hydride addition, giving rise to $\mathbf{1 3}$. Best results in the key step, the $\alpha$-hydroxylation, were obtained by deprotonation of 13 with NaHMDS at $-78^{\circ} \mathrm{C}$, followed by addition of Davis reagent. Herewith, the required $\alpha$-hydroxylated ester $\mathbf{1 4}$ was formed as single diastereomer. Other bases or protecting groups gave lower yields. Subsequent $O$-silylation provided the fully protected ester $\mathbf{1 5}$ in $31 \%$ over the whole sequence (from valinol). Saponification of the ester and coupling with $(S)$-serine methyl ester using DEPBT [3-(Diethoxy-phosphoryloxy)-3H-benzo[d] [1,2,3]triazin-4-one] [34] provided dipeptide 16, which could be cyclized to oxazoline derivative 17. This heterocycle has been found to be a suitable building block for several tubuvaline derivatives. Oxidation of $\mathbf{1 7}$ gave rise to the oxazole analogue 18, while the reaction with $\mathrm{H}_{2} \mathrm{~S}$ resulted in a ring opening towards the thioamide 19. Cyclization to 20 and oxidation provided the thiazole derivative $\mathbf{2 1}$ in high yield. Alternatively, the $O$-acetylated analogue 24 could be obtained from 14 via aminolysis of the ester followed by acetylation of the $\mathrm{OH}$-group (22). Treatment with Belleau reagent [35] generated thioamide $\mathbf{2 3}$, which could be subjected to a Hantzsch protocol [36] to provide thiazole 24.

During their synthesis towards tubulysin D, Ellman et al. developed a convergent synthesis based on the addition of a metalloenamine, derived from ketimine $\mathbf{2 5}$, to thiazoline aldehyde 26 (Scheme 4) [37]. This aldehyde could be prepared in four steps according to the literature [38]. The stereoselectivity in the addition step strongly depends on the counter ion used. While almost 1:1 mixtures are obtained with $\mathrm{Zn}^{2+}$ and $\mathrm{Mg}^{2+}$ as counter ions, an excellent yield and diastereoselectivity was observed in the presence of $\mathrm{ClTi}(\mathrm{O} i$ $\mathrm{Pr})_{3}$. Stereoselective reduction of the imine 27 at $-78{ }^{\circ} \mathrm{C}$ proceeded with high stereoselectivity without reduction of the methyl ester. After chromatography, the $N$-protected amino alcohol 28 was obtained in diastereomerically pure form. Cleavage of the $N$-protecting group provided the salt 29 in quantitative yield. A similar approach was recently used for the synthesis of triazole analogs by Yang et al. [39].

In 2007, Wipf et al. reported an alternative approach towards the $N$-methyl analog of tubuvaline (33) (Scheme 5) [40]. The previously synthesized derivatives 21 and 24 evolved problems during the cleavage of the Cbz-protecting group which could not be removed by catalytic hydrogenation (e.g. Pd/C) because of the thiazole moiety. Therefore, the synthesis of a $N$-Boc-protected derivative 33 was envisaged. Starting from $(S)$-valine the Boc-protected $N$-methylhomovaline aldehyde $\mathbf{3 0}$ was synthesized according to standard procedures. Addition of a thiazole Grignard reagent, generated from 31 by exchange with sec-butylmagnesium chloride, provided a separable 2:1 mixture of the two possible diastereomers of 32. The desired major isomer was acetylated, deprotected and oxidized to give the $\mathrm{N}$-Bocprotected tubuvaline derivative $\mathbf{3 3}$.

In the same year, Zanda et al. reported a total synthesis of the simplified tubulysins $\mathrm{U}$ and $\mathrm{V}$ using another protocol towards $N$-desalkyltubuvaline 11 (Scheme 6) [41]. Cysteine was condensed with pyruvaldehyde to thiazolidine derivative 34, which was oxidized to thiazole 35 with $\mathrm{MnO}_{2}$. Subsequent aldol condensation and aza-Michael addition of Boc$\mathrm{NH}_{2}$ gave rise to the protected $\beta$-amino ketone 36. Stereose- 
lective reduction of the keto group according to the CoreyBakshi-Shibata (CBS) protocol [42] provided the epimeric alcohols 37, which could easily be separated by flash chromatography. Saponification of the ethyl ester 37a gave access to the free acid $\mathbf{1 1}$ in almost quantitative yield. Alternatively, ketone $\mathbf{3 6}$ can also be prepared by addition of ketone 35 to $N$-Boc-protected isobutylimine, generated in situ [20].

$$
\text { (c) }
$$

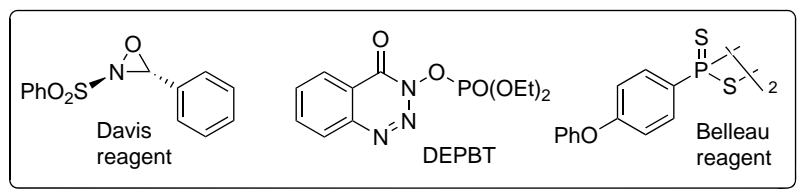

Scheme 3. Synthesis of Tuv derivatives $\mathbf{2 1}$ and $\mathbf{2 4}$ according to Wipf et al:: a) TEMPO, $\mathrm{NaOCl}, \mathrm{NaHCO}_{3}, \mathrm{NaBr} ;$ b) $\mathrm{Ph}_{3} \mathrm{PCHCO}_{2} \mathrm{Me}$; c) rac-Binap, NaOt-Bu, $\mathrm{CuCl}$, PMHS (polymethylhydrosiloxane), toluene, rt, 3 d; d) NaHMDS; e) Davis reagent, $\mathrm{THF},-78{ }^{\circ} \mathrm{C}$, $60 \mathrm{~min}$; f) TBDPSCl, imidazole, DMF, $60{ }^{\circ} \mathrm{C}$; g) $\mathrm{LiOH}, \mathrm{H}_{2} \mathrm{O}$; h) $(S)$-Ser-OMe, DEPBT, $\mathrm{NEt}_{3}$; i) DAST, $-78{ }^{\circ} \mathrm{C}$; k) $\mathrm{BrCCl}_{3}, \mathrm{DBU}, \mathrm{CH}_{2} \mathrm{Cl}_{2}, 0{ }^{\circ} \mathrm{C}, 7 \mathrm{~h}$; l) $\mathrm{H}_{2} \mathrm{~S}, \mathrm{MeOH}, \mathrm{NEt}_{3}, \mathrm{rt}, 3 \mathrm{~d}$; m) $\mathrm{NH}_{3}, \mathrm{MeOH}$; n) $\mathrm{Ac}_{2} \mathrm{O}$, pyridine; o) Belleau reagent; p) $\mathrm{BrCH}_{2} \mathrm{COCO}_{2} \mathrm{Et} ;$ q) $\mathrm{TFA}_{2} \mathrm{O}$, pyridine.

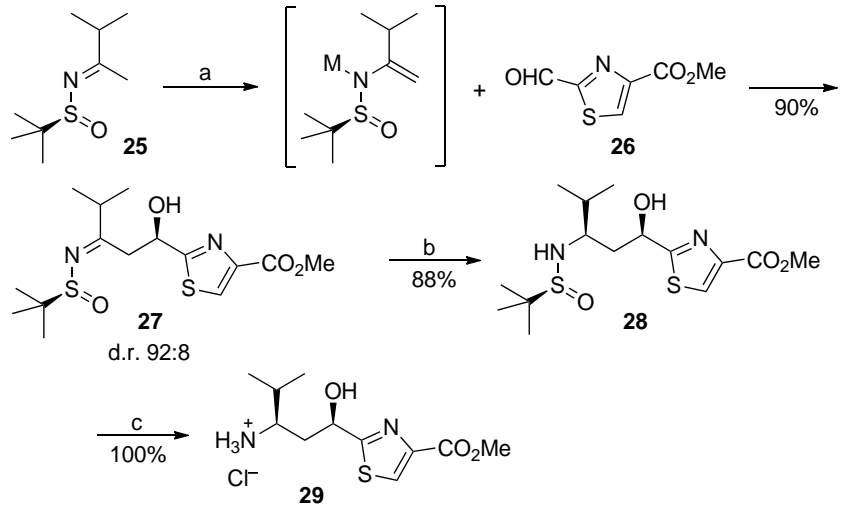

Scheme 4. Synthesis of Tuv derivative 29 according to Ellman et al.: a) LDA, ClTi $(\mathrm{O} i-\mathrm{Pr})_{3}, \mathrm{Et}_{2} \mathrm{O},-78{ }^{\circ} \mathrm{C}$; b $) \mathrm{NaBH}_{4}, \mathrm{Ti}(\mathrm{OEt})_{4},-78$ ${ }^{\circ} \mathrm{C}$; c) $\mathrm{HCl} /$ dioxane, $\mathrm{MeOH}$.

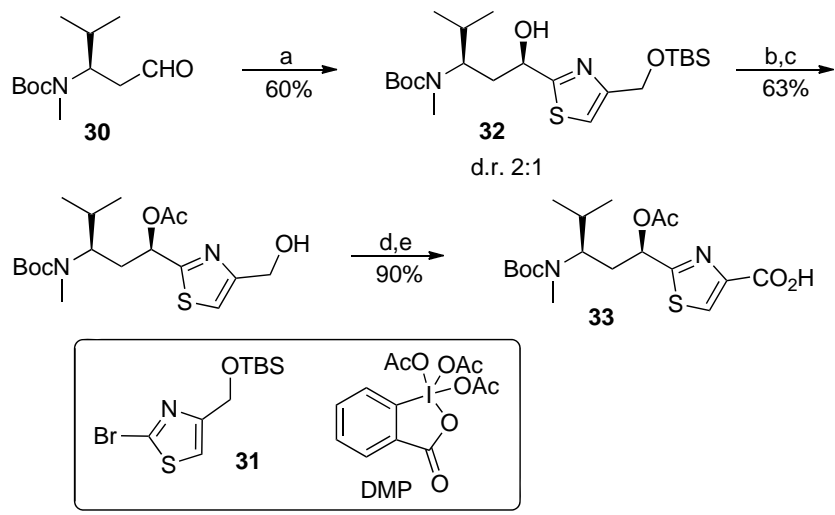

Scheme 5. Synthesis of Tuv derivative 33 according to Wipf et al: a) sec-BuMgCl, 31, THF; b) $\mathrm{Ac}_{2} \mathrm{O}$, pyridine; c) TBAF; d) DessMartin periodinane (DMP); e) $\mathrm{NaClO}_{2}, 2$-methyl-2-butene.

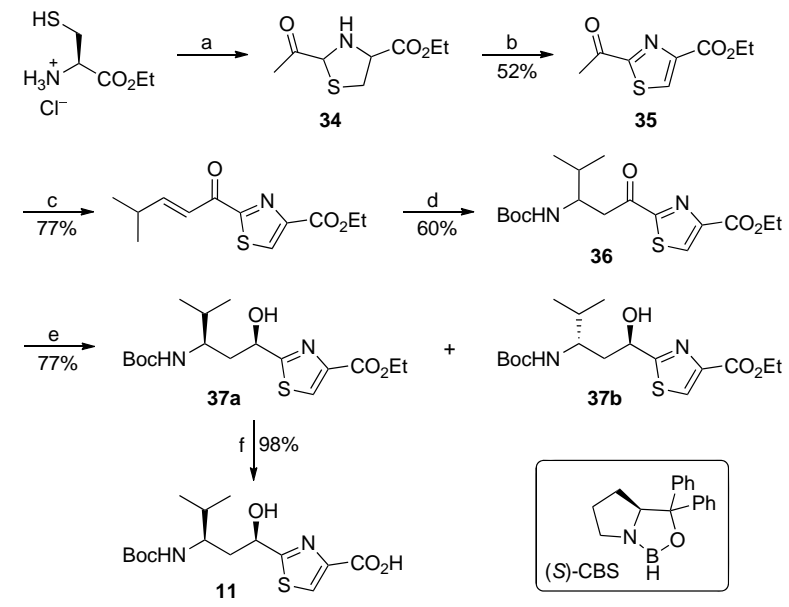

Scheme 6. Synthesis of Tuv derivative $\mathbf{1 1}$ according to Zanda et al.: a) Pyruvaldehyde, $\mathrm{NaHCO}_{3}, \mathrm{EtOH} / \mathrm{H}_{2} \mathrm{O}(1: 1), \mathrm{rt}, 18 \mathrm{~h}$; b) activated $\mathrm{MnO}_{2}, \mathrm{MeCN}, 50{ }^{\circ} \mathrm{C}, 2 \mathrm{~h}$; c) $i$-PrCHO, $\mathrm{TiCl}_{4}, \mathrm{NEt}_{3}$, dry THF, -78 ${ }^{\circ} \mathrm{C}$ to $\mathrm{rt}$; d) $\mathrm{BocNH}_{2}, \mathrm{Sn}(\mathrm{OTf})_{2}, \mathrm{MeCN}, \mathrm{rt}, 3 \mathrm{~h}$; e) (S)-CBS, $\mathrm{BH}_{3} \cdot \mathrm{Me}_{2} \mathrm{~S}$, dry THF, $0{ }^{\circ} \mathrm{C}$ to rt, $2 \mathrm{~h}$; f) $\mathrm{LiOH}, \mathrm{THF} / \mathrm{H}_{2} \mathrm{O} 4: 1$, rt, $5 \mathrm{~h}$. 
A very similar approach was used by Fecik et al. for the synthesis of a keto analogue of tubuvaline 42 (Scheme 7) [43]. A Wolff rearrangement of the valine derived diazoketone 38 was used to generate directly Weinreb amide 39. For the next step, the addition of a lithiated thiazole, generated from bromothiazole 40, the $N$-functionality was double protected. An excellent yield of the thiazolyl ketone 41 was obtained, which was converted into the simplified tubuvaline fragment 42 via desilylation and two-step oxidation of the primary alcohol functionality.

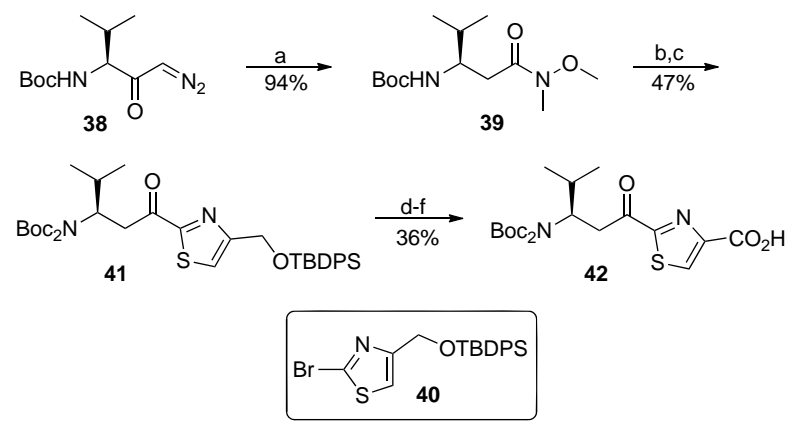

Scheme 7. Synthesis of Tuv derivative $\mathbf{4 2}$ according to Fecik et al: a) $\mathrm{CF}_{3} \mathrm{CO}_{2} \mathrm{Ag},(\mathrm{MeO}) \mathrm{NHMe} \cdot \mathrm{HCl}, \mathrm{NEt}_{3}$; b) LHMDS, $\mathrm{Boc}_{2} \mathrm{O}$; c) 40, $n$-BuLi; d) HF.pyridine, pyridine; e) Dess-Martin periodinane (DMP); f) $\mathrm{NaClO}_{2}, 2$-methyl-2-butene.

In 2009, Kazmaier et al. reported a straightforward synthesis of a desoxytubuvaline derivative $\mathbf{4 5}$ used in the synthesis of pretubulysin (Scheme 8) $[15,16]$. Starting from $N$ Boc-protected valine ester, DIBAL-H reduction to the corresponding aldehyde and subsequent Wittig reaction provided unsaturated nitrile 43. Catalytic hydrogenation, $N$ methylation and $\mathrm{H}_{2} \mathrm{~S}$-addition towards the nitrile functionality afforded thioamide $\mathbf{4 4}$ which was subjected to a Hantzsch synthesis to give thiazole derivative $\mathbf{4 5}$.

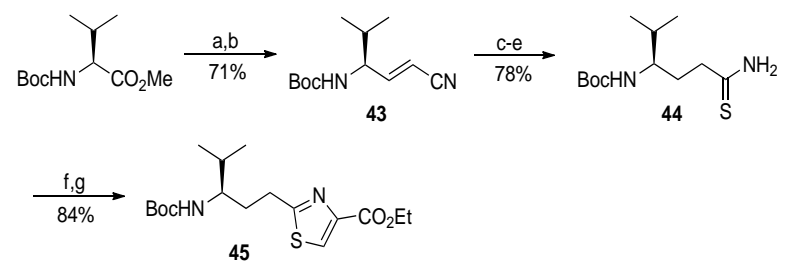

Scheme 8. Synthesis of Tuv derivative $\mathbf{4 5}$ according to Kazmaier $e t$ al.: a) DIBAL-H, toluene, $-78{ }^{\circ} \mathrm{C}$; b) $\mathrm{Ph}_{3} \mathrm{P}=\mathrm{CHCN}$; c) $\mathrm{H}_{2}, \mathrm{Pd} / \mathrm{C}$, $\mathrm{MeOH}$; d) $\mathrm{NaH}, \mathrm{MeI}, \mathrm{DMF}, 0{ }^{\circ} \mathrm{C}$; e) $\mathrm{H}_{2} \mathrm{~S}, \mathrm{NEt}_{3}, \mathrm{CHCl}_{3},-78{ }^{\circ} \mathrm{C}$ to $\mathrm{rt}$; f) $\mathrm{BrCH}_{2} \mathrm{COCO}_{2} \mathrm{Et}$, acetone, $-10{ }^{\circ} \mathrm{C}$; g) $\mathrm{TFA}_{2} \mathrm{O}$, pyridine, $\mathrm{CH}_{2} \mathrm{Cl}_{2},-30{ }^{\circ} \mathrm{C}$ to $\mathrm{rt}$.

In the same year, Chandrasekhar et al. described a multigram scale synthesis of the Tuv-Tup fragment using a new approach for tubuvaline (Scheme 9) [44]. Aziridine 46 was obtained from $(S)$-valine according to the literature [45]. 46 was opened regioselectively via $\mathrm{Cu}$-catalyzed allyl Grignard addition. Sodium naphthalide was used to remove the Ts-protecting group from $\mathbf{4 7}$ and the resulting free amine was double Boc-protected (48). Oxidative cleavage of the double bond provided aldehyde 49, which was subjected to an asymmetric $\alpha$-hydroxylation. Rapid reduction with
$\mathrm{NaBH}_{4}$ furnished an unstable anilinoxy compound, which was cleaved with $\mathrm{CuSO}_{4}$ to the corresponding diol 50. A three step protocol was used to get access to the selectively MOM-protected alcohol 51, which was oxidized to the aldehyde and directly converted into the thiazolidine 52. Oxidation with $\mathrm{MnO}_{2}$ and saponification of the ester provided MOM-protected tubuvaline derivative $\mathbf{5 3}$.

$$
\text { (2) }
$$

Scheme 9. Synthesis of Tuv derivative $\mathbf{5 3}$ according to Chandrasekhar et al.: a) AllylMgBr, CuCN, THF, $0{ }^{\circ} \mathrm{C}$ to rt, $4 \mathrm{~h}$; b) Sodium naphthalide, THF, $-20{ }^{\circ} \mathrm{C}, 1 \mathrm{~h}$; c) $\mathrm{Boc}_{2} \mathrm{O}, \mathrm{NEt}_{3}, \mathrm{CH}_{2} \mathrm{Cl}_{2}, 0$ ${ }^{\circ} \mathrm{C}$ to $\mathrm{rt}, 30 \mathrm{~min}$; d) $1 . n$-BuLi, 2. $\mathrm{Boc}_{2} \mathrm{O}, \mathrm{THF},-78{ }^{\circ} \mathrm{C}$ to $\mathrm{rt}$; e) $\mathrm{OsO}_{4}, 2,6$-lutidine, $\mathrm{NaIO}_{4}$, dioxane $/ \mathrm{H}_{2} \mathrm{O}, 0{ }^{\circ} \mathrm{C}$ to $\mathrm{rt}, 30 \mathrm{~h}$; f) 1 . (S)-Pro, PhNO, DMSO; 2. $\mathrm{NaBH}_{4}, \mathrm{EtOH} ;$ g) $\mathrm{CuSO}_{4} \cdot 5 \mathrm{H}_{2} \mathrm{O}$, $\mathrm{MeOH}$; h) $\mathrm{TBSCl}$, imidazole, $\mathrm{CH}_{2} \mathrm{Cl}_{2}, 0{ }^{\circ} \mathrm{C}$ to $\mathrm{rt}$; i) $\mathrm{MOMCl}$, $\mathrm{CH}_{2} \mathrm{Cl}_{2}, 0{ }^{\circ} \mathrm{C}$ to $\mathrm{rt}$; k) TBAF, THF, $0{ }^{\circ} \mathrm{C}$ to $\mathrm{rt}$; l) 1 . $(\mathrm{COCl})_{2}$, DMSO, $\mathrm{CH}_{2} \mathrm{Cl}_{2},-78^{\circ} \mathrm{C}, 2 \mathrm{~h} ; 2$. $\mathrm{NEt}_{3}$, EtOH, $(R)$-Cys-OMe $\cdot \mathrm{HCl}, \mathrm{rt}$, $\left.2 \mathrm{~h} ; \mathbf{m}) \mathrm{MnO}_{2}, \mathrm{MeCN}, 50{ }^{\circ} \mathrm{C}, 20 \mathrm{~h} ; \mathbf{n}\right) \mathrm{LiOH}, \mathrm{THF} / \mathrm{H}_{2} \mathrm{O}$.

An interesting approach towards tubuvaline derivative 29 was developed by Tamura et al. during the synthesis of several tubulysins (Scheme 10) [46,47]. Key step of their synthesis is a $[3+2]$-cycloaddition of a $D$-gulose derived nitrone 54 with an $\alpha, \beta$-unsaturated amide 55 containing camphor sultam as a second chiral auxiliary. Although the chiral induction of the nitrone was modest, a rather good diastereoselectivity (d.r. 85:15) for the coupling product $\mathbf{5 6}$ could be obtained due to double asymmetric induction conditions. The required stereoisomer was formed preferentially. The chiral auxiliaries could be removed stepwise by $\mathrm{LiOH}$ and $\mathrm{HClO}_{4}$, respectively. Afterwards, the free amino functionality was Fmoc-protected (57). Coupling with $S$-tritylated cysteine provided the fully protected dipeptide 58. The thiazole ring (59) was formed after cleavage of the $S$-protecting group, cyclization and subsequent $\mathrm{MnO}_{2}$ oxidation. Finally, reductive cleavage of the $\mathrm{N}-\mathrm{O}$ bond with $\mathrm{Mo}(\mathrm{CO})_{6}$ and subsequent Fmoc-cleavage gave rise to tubuvaline derivative 29.

Recently, Zanda et al. reported the synthesis of oxazole derivatives 63 of tubuvaline in analogy to their tubuvaline protocol (Scheme 11) [22]. Ketooxazole 60 was obtained from lactic acid and serine and was subjected to an aldoltype addition using $N$-Boc-protected isobutyraldimine, generated in situ from amino sulfone 61. $\beta$-Aminoketone 62 was obtained as a racemic mixture. Stereoselective reduction according to Corey-Bakshi-Shibata gave rise to a mixture of the diastereomeric alcohols $\mathbf{6 3}$ which could be separated by flash chromatography. The first step of the sequence could also be carried out in a highly diastereoselective fashion using chiral sulfimines [48]. 

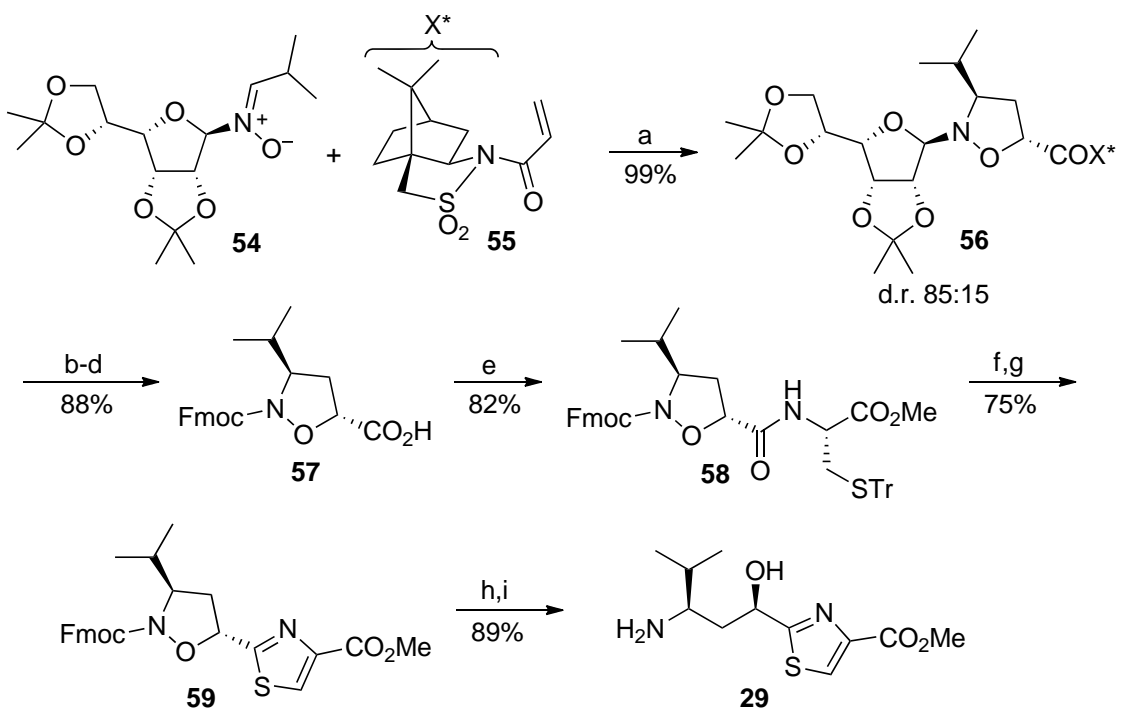

Scheme 10. Synthesis of Tuv derivative 29 according to Tamura et al: a) $\mathrm{CH}_{2} \mathrm{Cl}_{2}, 40{ }^{\circ} \mathrm{C}, 48 \mathrm{~h}$; b) $\left.\mathrm{LiOH}, \mathrm{THF} / \mathrm{H}_{2} \mathrm{O} ; \mathbf{c}\right)$ aq. $\mathrm{HClO}$, $\mathrm{MeCN}$; d) Fmoc-Cl, $\mathrm{NaHCO}_{3}$, dioxane/ $\left.\mathrm{H}_{2} \mathrm{O} ; \mathbf{e}\right)(R)$-Cys(STr)-OMe, HATU, DIPEA, $\mathrm{CH}_{2} \mathrm{Cl}_{2} ;$ f) $\left.\left.\mathrm{Ph}_{3} \mathrm{P}=\mathrm{O}, \mathrm{Tf}_{2} \mathrm{O}, \mathrm{CH}_{2} \mathrm{Cl}_{2} ; \mathbf{g}\right) \mathrm{MnO}_{2}, \mathrm{CH}_{2} \mathrm{Cl}{ }_{2} ; \mathbf{h}\right) \mathrm{Mo}_{(\mathrm{CO})}$, $\mathrm{MeCN} / \mathrm{H}_{2} \mathrm{O}$; i) $\mathrm{Et}_{2} \mathrm{NH}, \mathrm{MeCN}$.

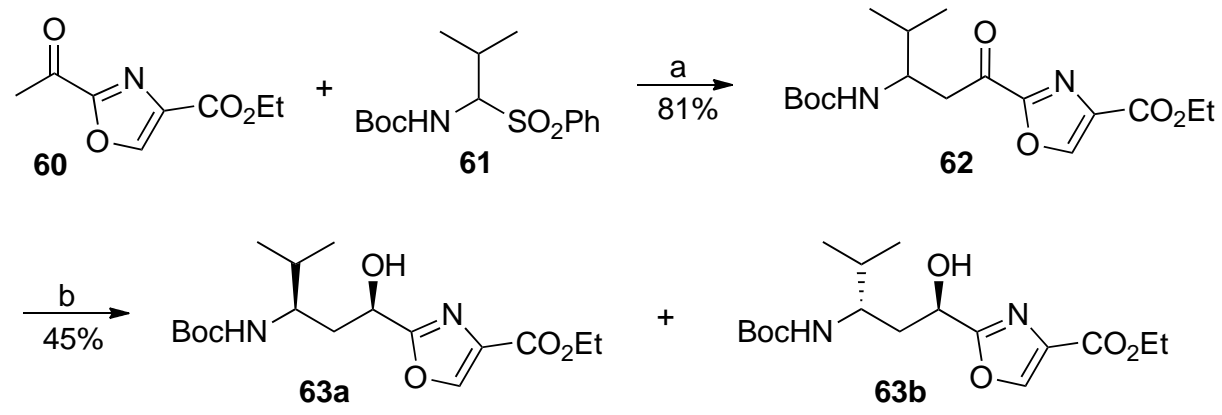

Scheme 11. Synthesis of Tuv derivatives 63 according to Zanda et al.: a) NaH, THF, 2-3 h; b) (S)-(-)-2-methyl-CBS-oxazaborolidine, $\mathrm{BH}_{3} \cdot \mathrm{SMe}_{2}, \mathrm{THF}, 0^{\circ} \mathrm{C}, 2-3 \mathrm{~h}$.

\section{SYNTHESES OF TUBUPHENYLALANINE AND ITS DERIVATIVES}

The first synthetic approaches towards tubuphenylalanine (Tup) were reported by Höfle et al. in their patent from 2001 (Scheme 12) [26]. Boc-protected (S)-phenylalaninol was oxidized according to the Swern protocol, and the resulting aldehyde was subjected to a Horner-Wadsworth-Emmons reaction, providing a mixture of lactam 64 and unsaturated ester 65. After separation, the two compounds were hydrogenated. While the open chain compound $\mathbf{6 0}$ gave rise to a 2:1 diastereomeric mixture of $\mathbf{6 6}$, the unsaturated lactam $\mathbf{6 4}$ provided unfortunately the undesired stereoisomer of lactam 67 preferentially. Saponification and esterification yielded the undesired diastereomer $\mathbf{6 8}$ of Tup.

Therefore, a second approach was developed leading to the correct stereoisomer (Scheme 13) [26]. In analogy to the previous approach $(S)-N$-Boc-phenylalaninol was subjected to oxidation, Wittig olefination and subsequent hydrogenation to give protected $\gamma$-amino acid ester 69. Obviously no lactam formation was observed, also in the subsequent step, the formation of the $N$-acyloxazolidin-2-one 70. This chiral auxiliary was used to introduce the $\alpha$-methyl group stereoselectively, providing the requested Tup derivates $\mathbf{7 1}$ and $\mathbf{7 2}$.

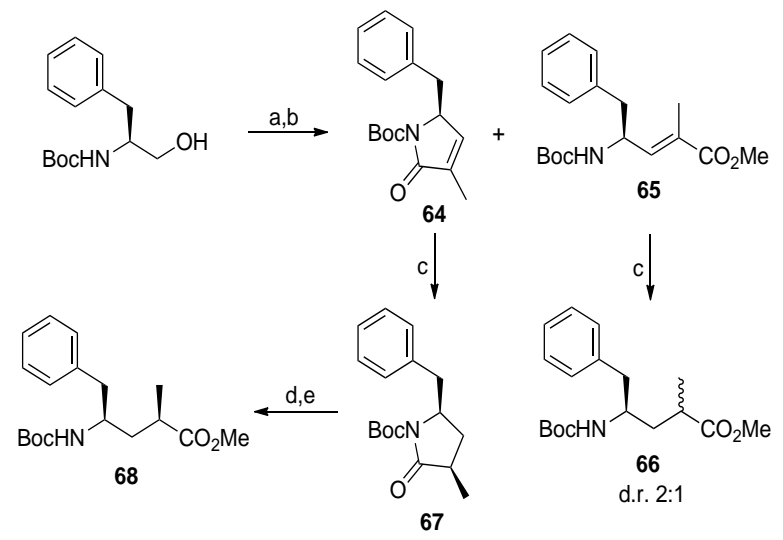

Scheme 12. Synthesis of Tup derivatives 66 and $\mathbf{6 8}$ according to Höfle et al.: a) Swern oxidation; b) $n$-BuLi, $(\mathrm{EtO})_{2} \mathrm{P}(\mathrm{O}) \mathrm{CH}\left(\mathrm{CH}_{3}\right) \mathrm{CO}_{2} \mathrm{Me}$; c) $\mathrm{Pd} / \mathrm{C}, \mathrm{H}_{2} ;$ d) $\mathrm{LiOH}, \mathrm{H}_{2} \mathrm{O}_{2} ;$ e) $\mathrm{CH}_{2} \mathrm{~N}_{2}$.

Also in patents, researchers at Morphochem described a related approach based on an auxiliary-controlled $C-C$ coupling (Scheme 14) [27,28]. Nucleophilic attack of deprotonated $N$-propionyloxazolidinone $\mathbf{7 3}$ on triflate $\mathbf{7 4}$, easily 


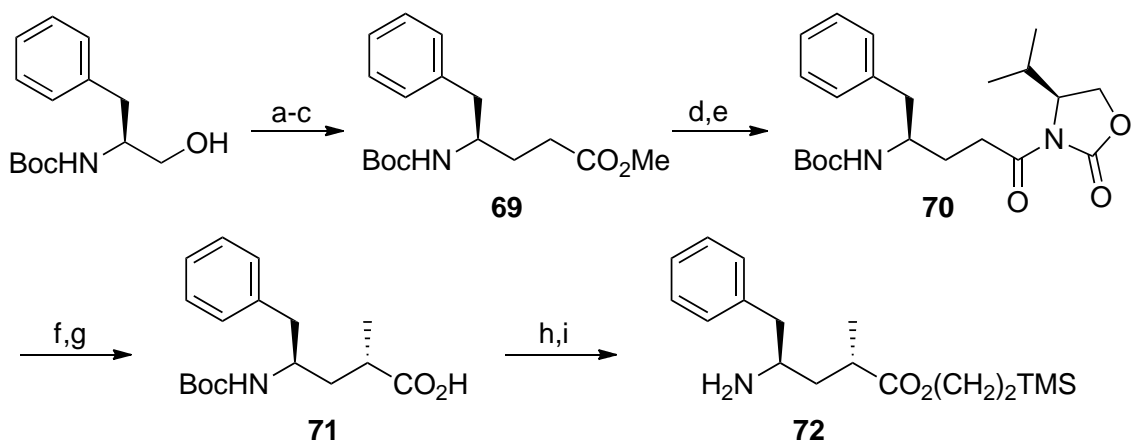

Scheme 13. Synthesis of Tup derivatives $\mathbf{7 1}$ and $\mathbf{7 2}$ according to Höfle et al.: a) Swern oxidation; b) Wittig reaction; c) $\mathrm{H}_{2}, \mathrm{Pd} / \mathrm{C}$; d) $\mathrm{NaOH}$, $\mathrm{H}_{2} \mathrm{O}$; e) 1. pivaloyl chloride, $\mathrm{Et}_{3} \mathrm{~N}$; 2. (S)-4-isopropyloxazolidin-2-one; f) $\left.\mathrm{NaHMDS}, \mathrm{MeI} ; \mathbf{g}_{2} \mathrm{H}_{2} \mathrm{O}_{2}, \mathrm{LiOH} ; \mathbf{h}\right) \mathrm{TMS}\left(\mathrm{CH}_{2}\right)_{2} \mathrm{OH}, \mathrm{DCC}$; i) TFA, $\mathrm{CH}_{2} \mathrm{Cl}_{2}$.

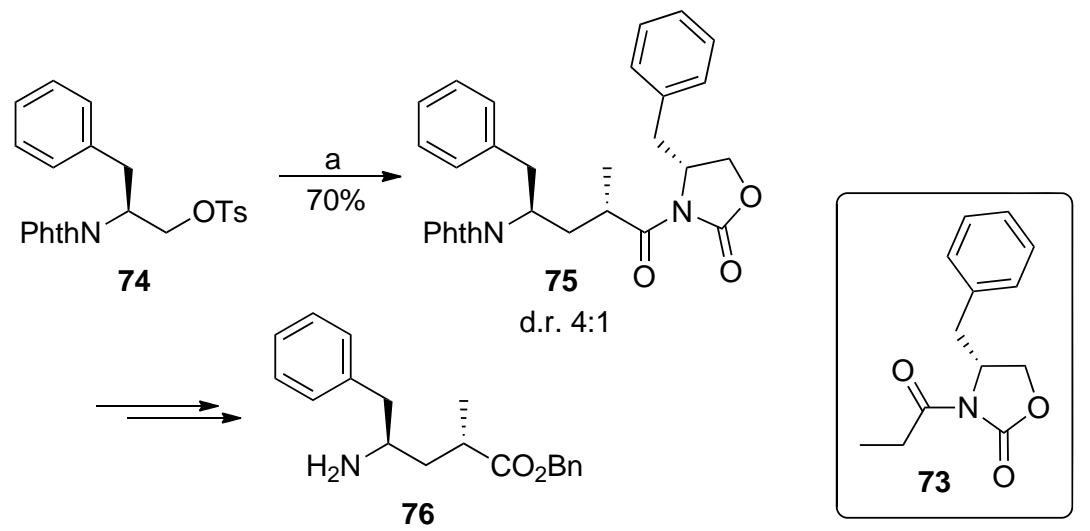

Scheme 14. Synthesis of Tup derivative 76 according to Dömling et al.: a) 73, LHMDS, $-40{ }^{\circ} \mathrm{C}$, THF.

obtained from $N$-phthaloyl- $(S)$-phenylalanine, provided protected Tup-derivative $\mathbf{7 5}$ as a $4: 1$ diastereomeric mixture. Separation of the diastereomers and subsequent cleavage of protecting and auxiliary groups gave access to Tup derivative $\mathbf{7 6}$.

During their synthesis of the Tuv-Tup-fragment, Wipf et al. used an approach for Tup very similar to the Höfle group (Scheme 15) [32]. They undertook a fairly stereocontrolled hydrogenation of $\alpha, \beta$-unsaturated carboxylic acid obtained from 65. However, they used the $O$-protected amine 77 in their peptide coupling step.

Also in 2004, Friestad et al. reported an interesting approach based on a Mn-mediated coupling of functionalized iodide 78 with a chiral modified hydrazone 79, giving access to oxazolidinone $\mathbf{8 0}$ in excellent diastereoselectivity (Scheme 16) [49]. The TFA-protected Tup derivative $\mathbf{8 1}$ was obtained after cleavage of the hydrazine and silyl ether and subsequent oxidation of the primary alcohol.
In 2006, Ellman et al. described a straightforward protocol towards unprotected Tup 84 in only three steps from commercially available starting materials (Scheme 17) [37]. Key step was a $\mathrm{SmI}_{2}$ mediated reductive coupling of methyl methacrylate and phenylacetaldimine 82, obtained form $(R)$ tert-butane-sulfinamide and phenylacetaldehyde. Diastereomerically pure 83 could be obtained after chromatography. Subsequent ester hydrolysis and cleavage of the sulfinyl group gave rise to $\mathbf{8 4}$ in quantitative yield.

In the same year, Dömling and Wessjohann et al. described a synthesis via an asymmetric aziridine ring opening using pseudoephedrine derived propionamide 85 (Scheme 18) [29]. Unfortunately, this approach generated the undesired configuration of the methyl group at the $\alpha$-position (87) [50]. Cleavage of the auxiliary and the $N$-protecting group provided epi-Tup derivative $\mathbf{8 8}$.

Shortly thereafter the authors presented another approach, based on Enders' SAMP auxiliary [51]. With

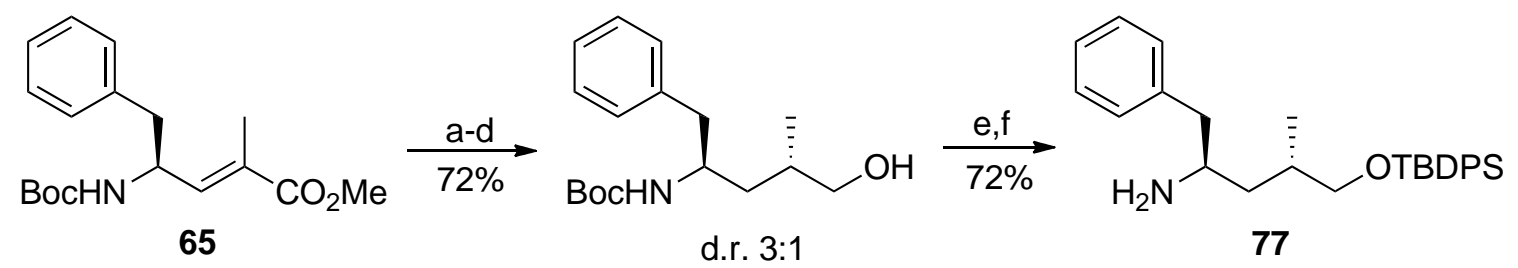

Scheme 15. Synthesis of Tup derivative 77 according to Wipf et al.: a) $\mathrm{NaOH}$; b) $\mathrm{H}_{2}, \mathrm{Pd} / \mathrm{C}$; c) $i-\mathrm{BuOCOCl}_{2} \mathrm{Et}_{3} \mathrm{~N}$; d) $\mathrm{NaBH}_{4}$; e) $\mathrm{TBDPSCl}$, imidazole; f) TFA, PhSMe. 

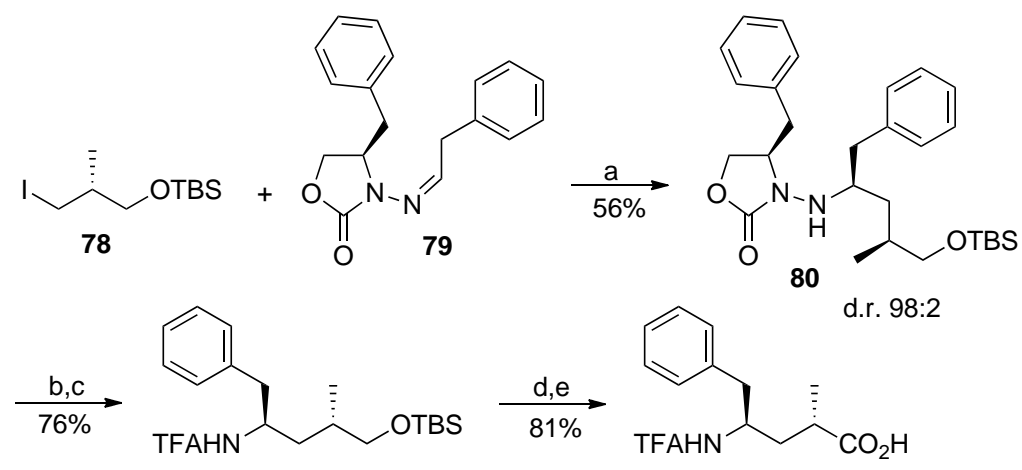

81

Scheme 16. Synthesis of Tup derivative 81 according to Friestad et al.: a) $\mathrm{Mn}_{2}(\mathrm{CO})_{10}$, hv, $\mathrm{InCl}_{3}, \mathrm{CH}_{2} \mathrm{Cl}_{2} ;$ b) TFA $\mathrm{O}, \mathrm{DMAP}_{\text {, pyridine; }}$ c) $\mathrm{SmI}_{2}, \mathrm{MeOH}$; d) TBAF, THF; e) $\mathrm{PhI}(\mathrm{OAc})_{2}$, TEMPO.

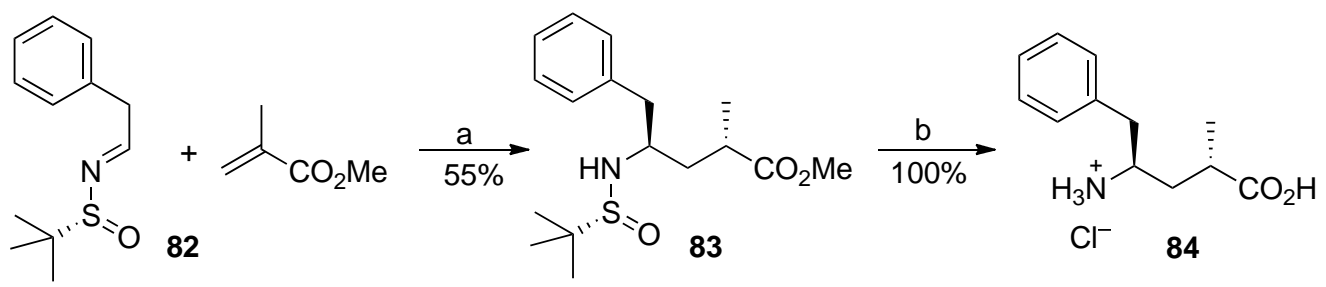

Scheme 17. Synthesis of Tup derivative 84 according to Ellman et al.: a) $\mathrm{SmI}_{2}, \mathrm{LiBr}, \mathrm{H}_{2} \mathrm{O}, \mathrm{THF},-78^{\circ} \mathrm{C}$; b) $\mathrm{HCl}$, dioxane/ $\mathrm{H}_{2} \mathrm{O}, \Delta$.<smiles>CCC(=O)N(C)[C@@H](C)[C@H](O)c1ccccc1</smiles><smiles>C[C@@H]([C@H](O)c1ccccc1)N(C)C(=O)[C@H](C)C[C@H](Br)Cc1ccccc1</smiles><smiles>CC(=O)[C@H](C)C[C@H]([NH3+])Cc1ccccc1</smiles>

d.r. $81: 19$

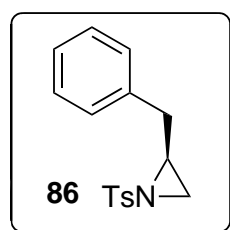

Scheme 18. Synthesis of epi-Tup derivative $\mathbf{8 8}$ according to Dömling and Wessjohann et al.: a) 1 . LDA, LiCl, THF, $-78{ }^{\circ} \mathrm{C} ; 2.86, \mathrm{THF},-20$ ${ }^{\circ} \mathrm{C}$; b) $4 \mathrm{M} \mathrm{H}_{2} \mathrm{SO}_{4} /$ dioxane, reflux; c) $\mathrm{MeOH}$, conc. $\mathrm{HCl}$, reflux; d) $\mathrm{Boc}_{2} \mathrm{O}$, DMAP, MeCN; e) $\mathrm{Mg}$ (powder), $\mathrm{MeOH}$, ultrasound; h) $4 \mathrm{~N}$ $\mathrm{HCl} /$ dioxane.

hydrazone 89 , the ring opening of the same aziridine 86 provided the desired product $\mathbf{9 0}$ with the correct configuration (Scheme 19) [50].

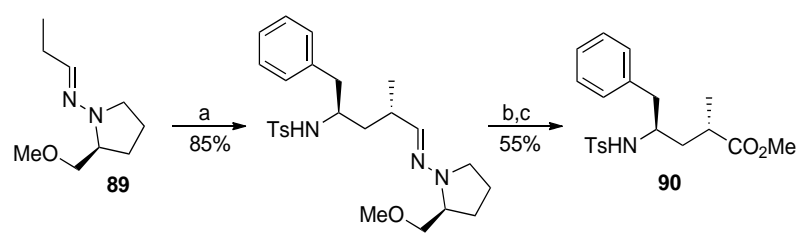

Scheme 19. Synthesis of Tup derivative 90 according to Dömling and Wessjohann et al.: a) 1 . LDA, $0{ }^{\circ} \mathrm{C} ; 2.86$, THF, $-100{ }^{\circ} \mathrm{C}$ to rt; b) $1 . \mathrm{O}_{3}$, acetone, $-78{ }^{\circ} \mathrm{C}$; 2 . Jones reagent, $-78{ }^{\circ} \mathrm{C}$ to rt; c) $\mathrm{CH}_{2} \mathrm{~N}_{2}$, $\mathrm{Et}_{2} \mathrm{O} / \mathrm{MeOH}$.

At the same time, Zanda et al. described the synthesis of enantiopure Tup 84 obtained by a chromatographic separation of the diastereomeric menthyl esters (Scheme 20) [41].
Starting from the same $N$-protected triflate $\mathbf{7 4}$, previously used by the Morphochem group, a $\mathrm{S}_{\mathrm{N}} 2$ reaction of deprotonated methyl malonate generated the quaternary $\gamma$-amino malonate derivative 91. Simultaneous cleavage of all protecting groups and decarboxylation provided unprotected Tup $\mathbf{9 2}$ as a 1:1 diastereomeric mixture. Conversion of $\mathbf{9 2}$ into the $\mathrm{N}$ Boc-protected menthyl ester $\mathbf{9 3}$ allowed the separation of the stereoisomers by flash chromatography.

In 2008, Fecik et al. described the synthesis of Tup derivative 97 based on an asymmetric methylation of lactam 94 (Scheme 21) [43]. Initial attempts using LDA or LHMDS and MeI resulted in low yields and diastereoselectivities in favor of the desired product $\mathbf{9 5}$. The major side product was the dimethylated lactam. But with NaHMDS as a base, the yield and selectivity for $\mathbf{9 5}$ could be increased to a synthetically useful value. Saponification of the lactam ring and protection of the free carboxylic acid yielded the protected Tup derivative 97 as well as the corresponding dimethylated 

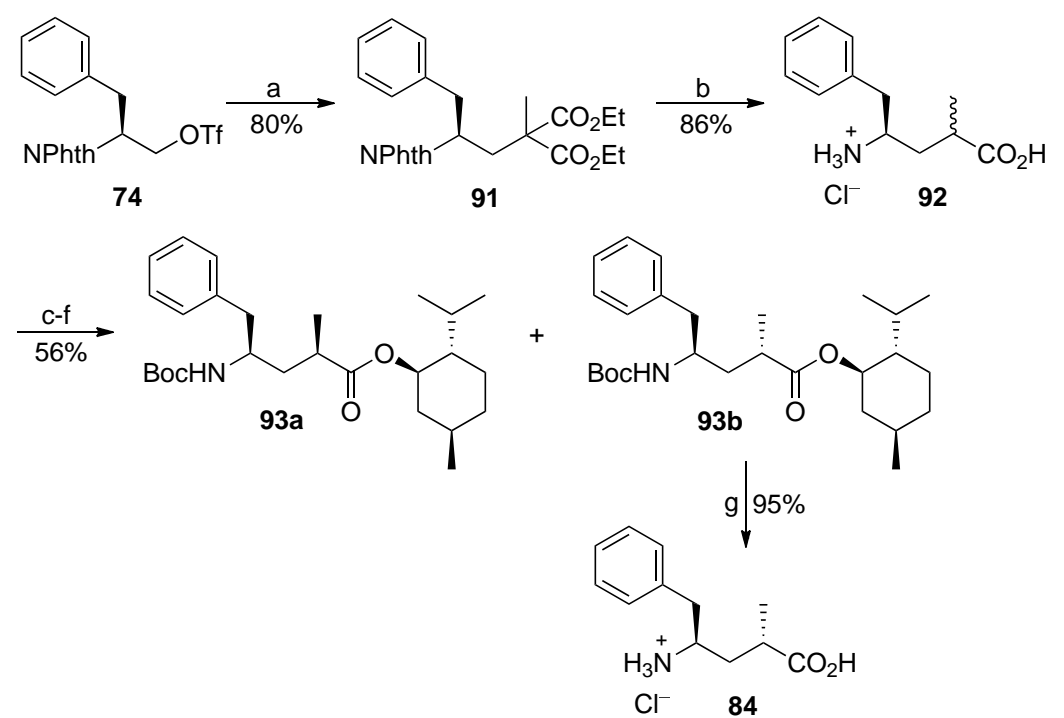

Scheme 20. Synthesis of Tup 84 according to Zanda et al.: a) Diethyl 2-methylmalonate, $\mathrm{NaH}, 0{ }^{\circ} \mathrm{C}, \mathrm{rt}, 7 \mathrm{~h}$; b) $6 \mathrm{~N} \mathrm{HCl}, \mathrm{AcOH}, 145{ }^{\circ} \mathrm{C}, 2 \mathrm{~d}$; c) 2,2-dimethoxypropane, conc. $\mathrm{HCl}, \mathrm{MeOH}, 60^{\circ} \mathrm{C}, 1 \mathrm{~d}$; d) $\mathrm{Boc}_{2} \mathrm{O}, \mathrm{Et}_{3} \mathrm{~N}, \mathrm{MeCN}, 6 \mathrm{~h}$; e) $\mathrm{LiOH}, \mathrm{H}_{2} \mathrm{O} / \mathrm{THF}, 1 \mathrm{~d}$; f) (-)-menthol, DCC, DMAP, $\mathrm{CH}_{2} \mathrm{Cl}_{2}, 6 \mathrm{~h}$; then flash chromatography to separate 93a from 93b; g) $6 \mathrm{~N} \mathrm{HCl}, 130{ }^{\circ} \mathrm{C}, 1.5 \mathrm{~h}$.

derivative, which were both incorporated into tubulysin derivatives [52].
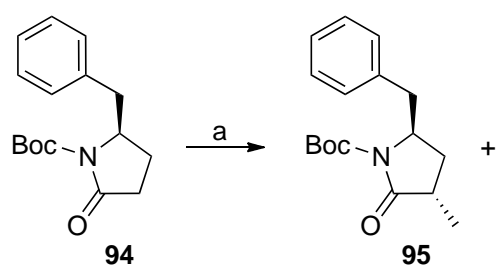

95

$52 \%$, d.r. $10: 1$<smiles>C[C@H](C[C@H](Cc1ccccc1)NC(=O)OCc1ccccc1)C(=O)Oc1ccccc1</smiles>

97

Scheme 21. Synthesis of Tup 97 according to Fecik et al.: a) 1 . NaHMDS, THF, $-78{ }^{\circ} \mathrm{C}$; 2 . MeI, $-78{ }^{\circ} \mathrm{C}$ to rt; b) LiOH; c) DBU, $\mathrm{BnBr}$.

In 2009, Kazmaier et al. described an approach based on the previous work of Wipf [32] and Zanda [41]. Starting from $N$-Boc protected Phe-OMe, reduction, in situ Wittig olefination and subsequent transesterification provided $\alpha, \beta$ unsaturated menthyl ester 98, which was subjected to catalytic hydrogenation (Scheme 22) $[15,16]$. The desired stereoisomer 99 was formed preferentially (diastereomeric ratio 3:1), and after chromatographic separation and deprotection, Tup ester $\mathbf{1 0 0}$ was obtained in almost diastereomerically pure form.

Tamura et al. took advantage of an Evans aldol reaction [53] of the (Z)-boron enolate of oxazolidinone 101 and $N$ protected phenylalaninal 102 (Scheme 23) [47]. The expected aldol product $\mathbf{1 0 3}$ was obtained in good yield and as single stereoisomer, probably as the result of double stereoinduction. The $\mathrm{OH}$-functionality formed was removed using the Barton-McCombie protocol [54]. Subsequent cleavage of the auxiliary and the Cbz-protecting group provided Tup 84.
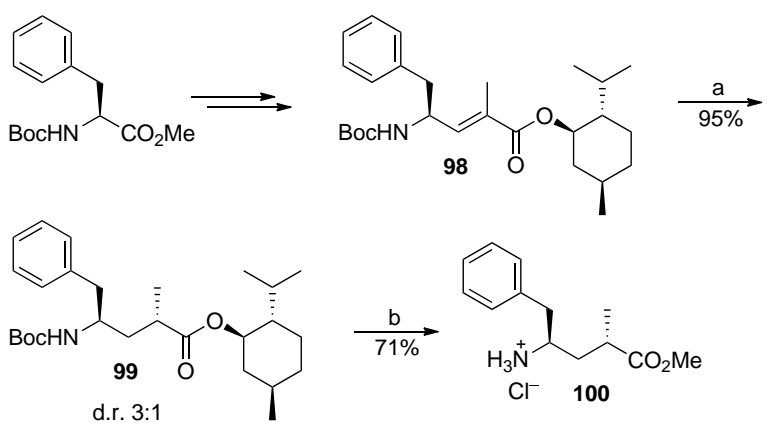

Scheme 22. Synthesis of Tup $\mathbf{1 0 0}$ according to Kazmaier et al.: a) $\mathrm{H}_{2}, \mathrm{Pd} / \mathrm{C}, \mathrm{MeOH}$; b) 1. chromatographic separation; 2. $6 \mathrm{~N} \mathrm{HCl}, 140$ ${ }^{\circ} \mathrm{C}$; 3. dimethoxypropane, cat. $\mathrm{HCl}, \mathrm{MeOH}, 50{ }^{\circ} \mathrm{C}$.

In 2011, Zanda et al. described the synthesis of Tup derivatives $\mathbf{8 4}$ and $\mathbf{1 0 0}$ similar to several previous approaches (Scheme 24) [22]. Phthaloyl-protected phenylalaninol was oxidized and subjected to a Wittig olefination to give $\alpha, \beta$ unsaturated ester 104, which was subsequently hydrogenated to protected Tup 105. The almost equimolar mixture of diastereomers was separated by flash chromatography. Cleavage of the phthaloyl protecting group resulted in the formation of lactam 106, which was specified to Tup 84.

Recently, Kazmaier et al. described an approach towards Tup derivative $\mathbf{1 0 0}$ based on an Ireland-Claisen rearrangement (Scheme 25) [54]. This approach allows easy variations of the $\alpha$-substituent $\mathrm{R}$ by using the corresponding allylic esters. Ireland-Claisen rearrangement of $\beta$-amino acid allyl ester $\mathbf{1 0 7}$ provided the corresponding carboxylate 108 in excellent yield but moderate diastereoselectivity. 

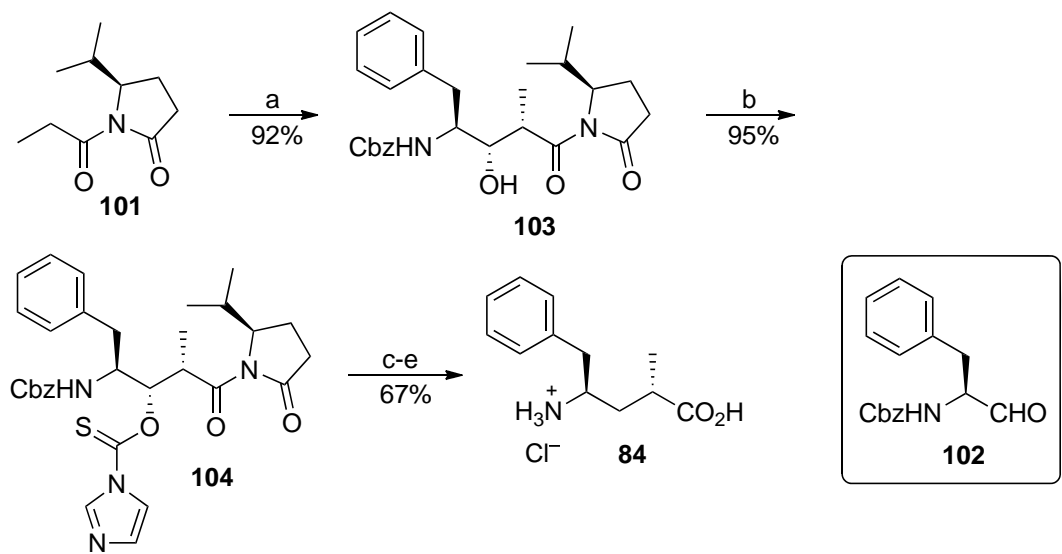

Scheme 23. Synthesis of Tup 84 according to Tamura et al:: a) 1. DIPEA, $\mathrm{Bu}_{2} \mathrm{BOTf}, \mathbf{1 0 2}, \mathrm{CH}_{2} \mathrm{Cl}_{2}$, then $30 \% \mathrm{H}_{2} \mathrm{O}_{2}, \mathrm{MeOH}$; b) Im ${ }_{2} \mathrm{CS}$, THF; c) $\mathrm{Bu}_{3} \mathrm{SnH}$, AIBN, toluene; d) $\mathrm{LiOH}, 30 \% \mathrm{H}_{2} \mathrm{O}_{2}, \mathrm{THF} / \mathrm{H}_{2} \mathrm{O}$; e) $\mathrm{H}_{2}, 10 \% \mathrm{Pd} / \mathrm{C}, 4 \mathrm{~N} \mathrm{HCl} /$ dioxane, THF.
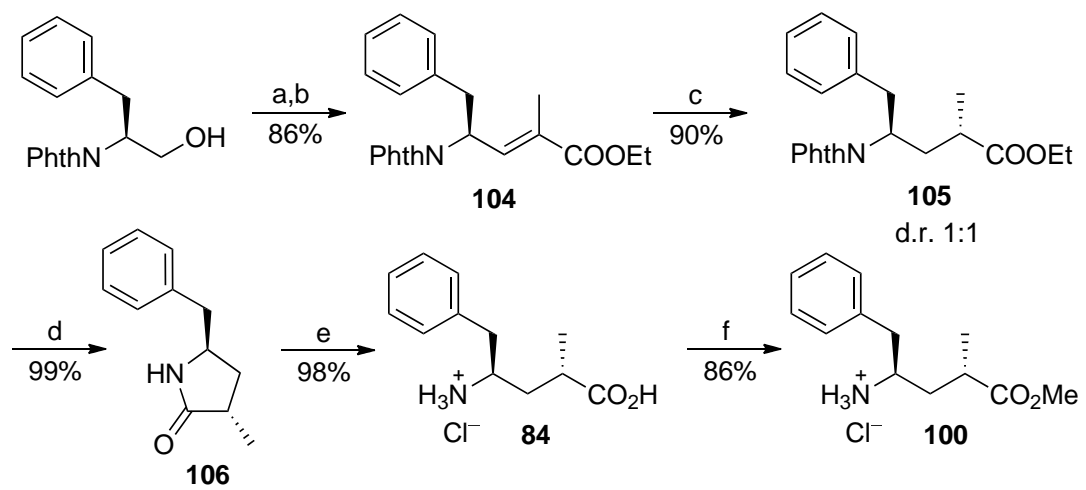

Scheme 24. Synthesis of Tup-derivatives $\mathbf{8 4}$ and $\mathbf{1 0 0}$ according to Zanda et al.: a) Dess-Martin periodinane, $\mathrm{NaHCO}_{3}, \mathrm{CH}_{2} \mathrm{Cl}_{2}, 90$ min; b) $\mathrm{CH}_{2} \mathrm{Cl}_{2}, \mathrm{Ph}_{3} \mathrm{PCMeCO}$ Et, $16 \mathrm{~h}$; c) $\mathrm{H}_{2}, \mathrm{Pd} / \mathrm{C}$, EtOAc, $16 \mathrm{~h}$, then chromatographic separation; d) $\mathrm{H}_{2} \mathrm{NNH}_{2} \cdot \mathrm{H}_{2} \mathrm{O}$, EtOH, reflux; e) $6 \mathrm{~N} \mathrm{HCl}, 145$ ${ }^{\circ} \mathrm{C}$; f) dimethoxypropane, cat. $\mathrm{HCl}, \mathrm{MeOH}$, reflux.

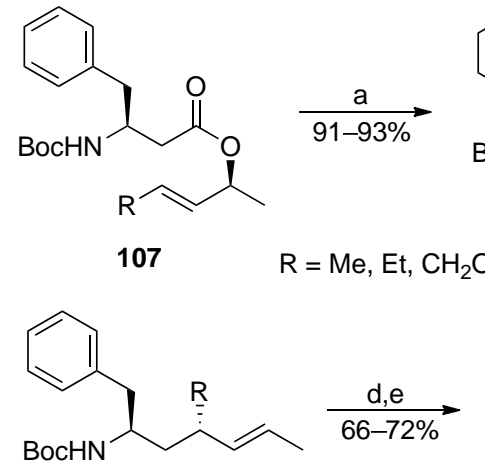

110

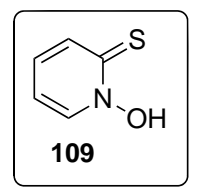

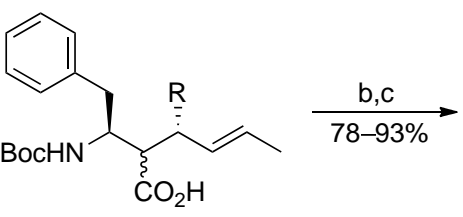

108

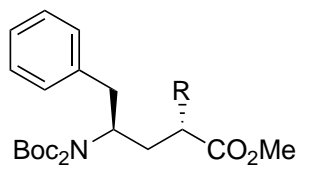

111

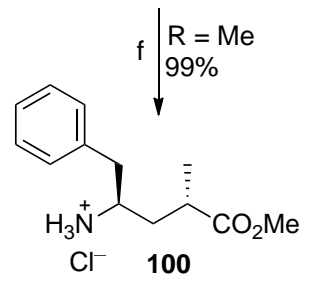

Scheme 25. Synthesis of the Tup 100 according to Kazmaier et al:: a) LDA, TMSCl, THF, $-78{ }^{\circ} \mathrm{C}$ to $60{ }^{\circ} \mathrm{C}, 2 \mathrm{~h}$; b) DCC, $\mathbf{1 0 9}$, DMAP, $\mathrm{CH}_{2} \mathrm{Cl}_{2}, 0{ }^{\circ} \mathrm{C}$ to rt; c) $t$-BuSH, $\mathrm{BEt}_{3}, \mathrm{O}_{2}$, THF, $0{ }^{\circ} \mathrm{C}$ to rt; d) $1 . n$ - $\mathrm{BuLi} ; 2$. $\mathrm{Boc}_{2} \mathrm{O}$, THF $-78{ }^{\circ} \mathrm{C}$ to $\left.60{ }^{\circ} \mathrm{C} ; \mathbf{e}\right) \mathrm{O}_{3}, \mathrm{CH}_{2} \mathrm{Cl}_{2}, \mathrm{NaOH} \mathrm{MeOH}-78$ ${ }^{\circ} \mathrm{C}$ to rt; f) $\mathrm{HCl} /$ dioxane, $0{ }^{\circ} \mathrm{C}$. 
Fortunately, the configuration at the $\alpha$-position does not play any role because the $\mathrm{COOH}$ group was removed, including this stereogenic centre, in the next step using the Barton method [55]. The carbamate (110) formed was double Bocprotected to avoid lactam formation in the next step, the ozonolysis using a protocol developed by Marshall et al. [56]. Cleavage of the Boc-protecting groups gave rise to the desired Tup-derivative $\mathbf{1 0 0}$.

\section{SYNTHESES OF TUV-TUP-FRAGMENTS}

In principle, with the different building blocks in hand, the tubulysins and derivatives thereof can be obtained by standard peptide couplings using a wide range of coupling reagents. Nevertheless, in some cases, not the finished (unusual) amino acids but precursors thereof were used in the coupling steps, mainly to avoid undesired side reactions.

Wipf et al. subjected building block 24 to saponification, and subsequent DEPBT-coupling with silyl protected Tupbuilding block 77 led to the dipeptide fragment 112 (Scheme 26) [32]. The secondary alcohol functionality was reacetylated in high yield. Cleavage of the silyl protecting group generated the free primary alcohol which was oxidized to the $N$-protected Tuv-Tup-fragment 113. The generation of the terminal acid functionality after the peptide coupling step solved the problem of $\gamma$-lactam formation in the coupling step.

A comparable strategy was used by Chandrasekhar et al. (Scheme 27) [44]. A suitable Tup precursor was obtained from a chiral protected epoxide 114 (synthesized from (-)citronellol) in six steps. This epoxide was treated with

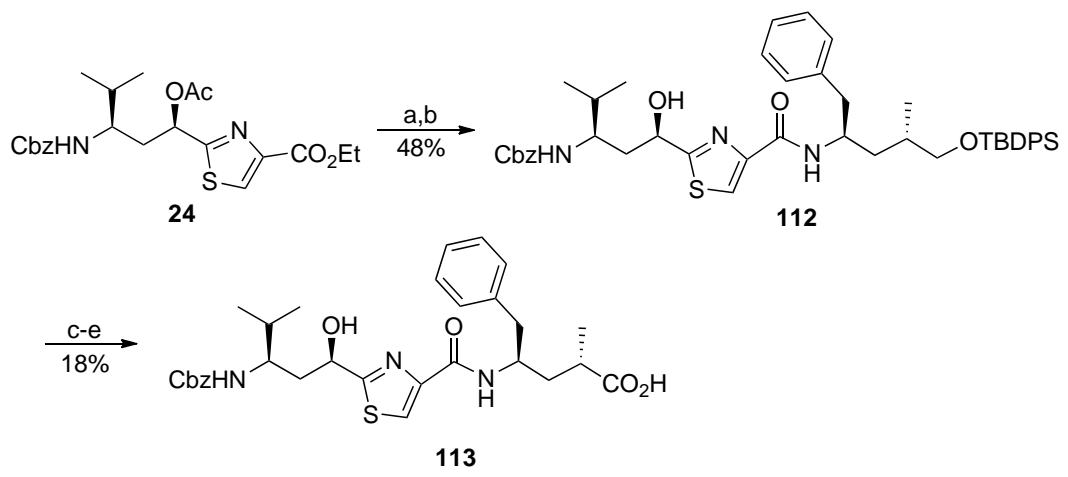

Scheme 26. Synthesis of Tuv-Tup fragment 113 according to Wipf et al.: a) $\mathrm{NaOH}, \mathrm{THF} / \mathrm{H}_{2} \mathrm{O}$; b) 77, DEPBT, DIPEA; c) Ac ${ }_{2} \mathrm{O}, \mathrm{pyridine}$; d) $\mathrm{HF}$, pyridine; TEMPO, $\mathrm{NaOCl}, \mathrm{NaOCl}_{2}, \mathrm{pH} 6.7, \mathrm{MeCN}$.
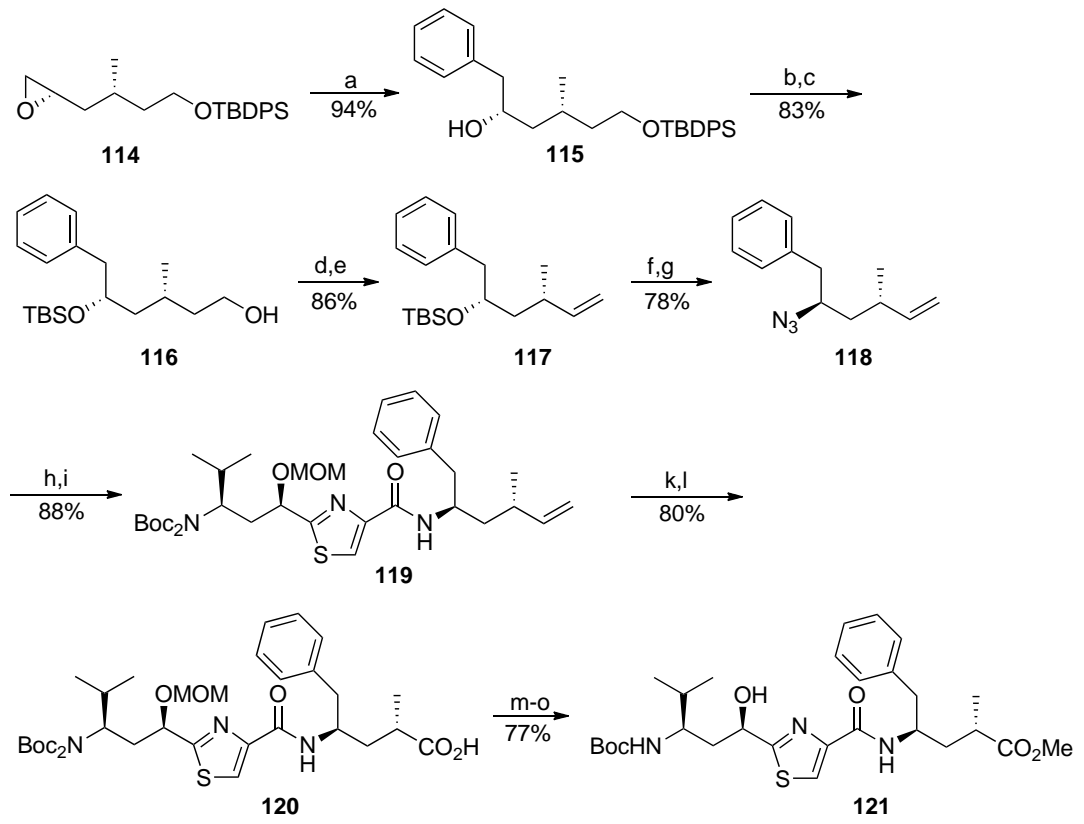

Scheme 27. Synthesis of Tuv-Tup fragment 119 according to Chandrasekhar et al:: a) $\mathrm{PhMgBr}, \mathrm{THF}, 0{ }^{\circ} \mathrm{C}, 3 \mathrm{~h}$; b) TBSCl, imidazole, $\mathrm{CH}_{2} \mathrm{Cl}_{2}, 0{ }^{\circ} \mathrm{C}$ to rt, $6 \mathrm{~h}$; c) $\mathrm{NH}_{4} \mathrm{~F}, \mathrm{MeOH}, \mathrm{rt}, 20 \mathrm{~h}$; d) $\mathrm{PPh}_{3}, \mathrm{I}_{2}$, imidazole, $\mathrm{Et}_{2} \mathrm{O} / \mathrm{MeCN}, 0{ }^{\circ} \mathrm{C}, 15$ min. e) $\mathrm{KO} t$ - $\mathrm{Bu}, \mathrm{THF}, 0{ }^{\circ} \mathrm{C}$ to rt, $20 \mathrm{~min} ; \mathbf{f}$ ) TBAF, THF, $0{ }^{\circ} \mathrm{C}$ to rt, $1 \mathrm{~h}$; g) $\mathrm{PPh}_{3}$, DIAD, DPPA, $0{ }^{\circ} \mathrm{C}, 45 \mathrm{~min}$; h) $\mathrm{LiAlH}_{4}, \mathrm{THF}, 0{ }^{\circ} \mathrm{C}, 30 \mathrm{~min}$; i) 53, $\mathrm{HOBt}, \mathrm{EDC}, \mathrm{DIPEA}^{\circ} \mathrm{CH}_{2} \mathrm{Cl}{ }_{2}, 0{ }^{\circ} \mathrm{C}$ to rt, 9 h; k) $\mathrm{OsO}_{4}, 2,6$-lutidine, $\mathrm{NaIO}_{4}$, dioxane $/ \mathrm{H}_{2} \mathrm{O}, 0{ }^{\circ} \mathrm{C}$ to rt, $20 \mathrm{~h}$; l) Bis(acetoxy)iodobenzene, TEMPO, MeCN/ $\left.\mathrm{H}_{2} \mathrm{O}, \mathrm{rt}, 1 \mathrm{~h} ; \mathbf{m}\right) \mathrm{CH}_{2} \mathrm{~N}_{2}$, $\left.\mathrm{Et}_{2} \mathrm{O}, 0{ }^{\circ} \mathrm{C}, 30 \mathrm{~min} ; \mathbf{n}\right) \mathrm{TFA} / \mathrm{CH}_{2} \mathrm{Cl}_{2}, 0{ }^{\circ} \mathrm{C}, \mathrm{rt}, 16 \mathrm{~h}$, then $\mathrm{NEt}_{3} ;$ o) $\mathrm{Boc}_{2} \mathrm{O}, \mathrm{CH}_{2} \mathrm{Cl}_{2}, 0{ }^{\circ} \mathrm{C}$ to $\mathrm{rt}, 30 \mathrm{~min}$. 
phenyl magnesiumbromide to give the ring-opened product 115 as a single regioisomer in excellent yield. The secondary alcohol formed was silylated and the primary TBDPS group was selectively cleaved off (116). The resulting terminal alcohol was subjected to elimination giving rise to terminal alkene 117. Cleavage of the silyl protecting group and Mitsunobu reaction with diphenylphosphoryl azide (DPPA) resulted in the formation of azide 118. Reduction of the azide functionality and coupling with the double Boc-protected Tuv-fragment 53 delivered the dipeptide fragment 119. The double bond was subjected to an oxidative cleavage and the corresponding aldehyde was directly oxidized to the triprotected Tuv-Tup fragment 120, which was converted into the Boc-protected peptide ester 121.

\section{SYNTHESIS OF TUBULYSINS A - D}

The first synthesis of tubulysins was reported by Höfle $e t$ al. in their patent from 2001, based on a fragment coupling strategy (Scheme 28) [26]. Two dipeptides were formed, one from $N$-methyl $(R)$-pipecolic acid and $(S)$-lle-OBn (122), and the other one from the oxo form of tubuvaline 6 and the Tup fragment 72 (123). After hydrogenolysis of the benzylic protecting groups, peptide coupling via a pentafluorophenyl ester intermediate generated tetrapeptide 124, which was reduced and subjected to functional group manipulations to provide the final tubulysin $\mathbf{1 2 5}$.

Ellman et al. described the first stereoselective synthesis of tubulysin D, the most biologically active derivative of the whole family (Scheme 29) [37,57]. Key step of their synthesis was the coupling of the $\alpha$-azido acid chloride $\mathbf{1 2 6}$ with Tuv-derivative 29. The azide masking group was chosen to allow a selective introduction of the $\mathrm{N}, \mathrm{O}$-acetal on the Tuv nitrogen of dipeptide 127. Protection of the secondary alcohol as TES-ether and subsequent $N$-alkylation gave rise to dipeptide 128. Advantageously, the azide group could be reduced under neutral conditions without affecting the sensitive $\mathrm{N}, \mathrm{O}$-acetal. $\mathrm{Pd}$-catalyzed hydrogenation in the presence of the Mep pentafluorophenyl ester followed by deprotection of the secondary alcohol provided tripeptide 129. The methyl ester could selectively be cleaved without affecting the<smiles>CC[C@H](C)[C@H](N)C(=O)OCc1ccccc1</smiles>

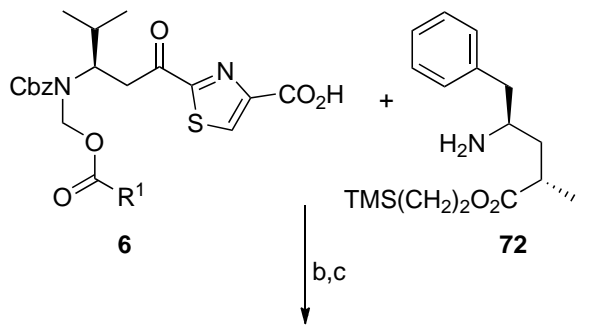<smiles>C[13CH3]</smiles><smiles>CC[C@H](C)[C@H](NC(=O)[C@@H]1CCCCN1C)C(=O)OCc1ccccc1</smiles>

122 ${ }_{2} \mathrm{Bn}$

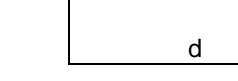

d

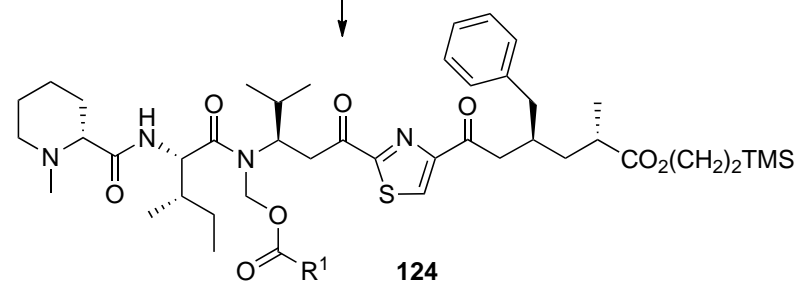

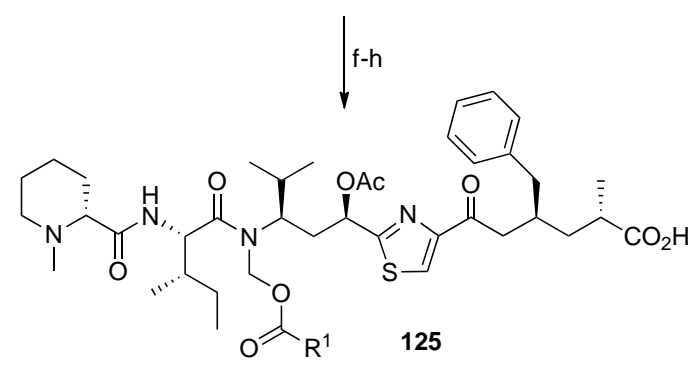

Scheme 28. Synthesis of tubulysins 125 according to Höfle et al.: a) diethyl cyanophosphonate, $\left.\mathrm{NEt}_{3} ; \mathbf{b}\right) \mathrm{C}_{6} \mathrm{~F}_{5} \mathrm{OH}, \mathrm{DCC}$; c) $\mathrm{NEt}_{3}$; d) $\left.\left.\left.\left.\mathrm{TFAOC}_{6} \mathrm{~F}_{5} ; \mathbf{e}\right) \mathrm{NEt}_{3}, \mathrm{H}_{2}, \mathrm{Pd} / \mathrm{C} ; \mathbf{f}\right) \mathrm{NaBH}_{4} ; \mathbf{g}\right) \mathrm{Ac}_{2} \mathrm{O} ; \mathbf{h}\right) \mathrm{TBAF}$. 


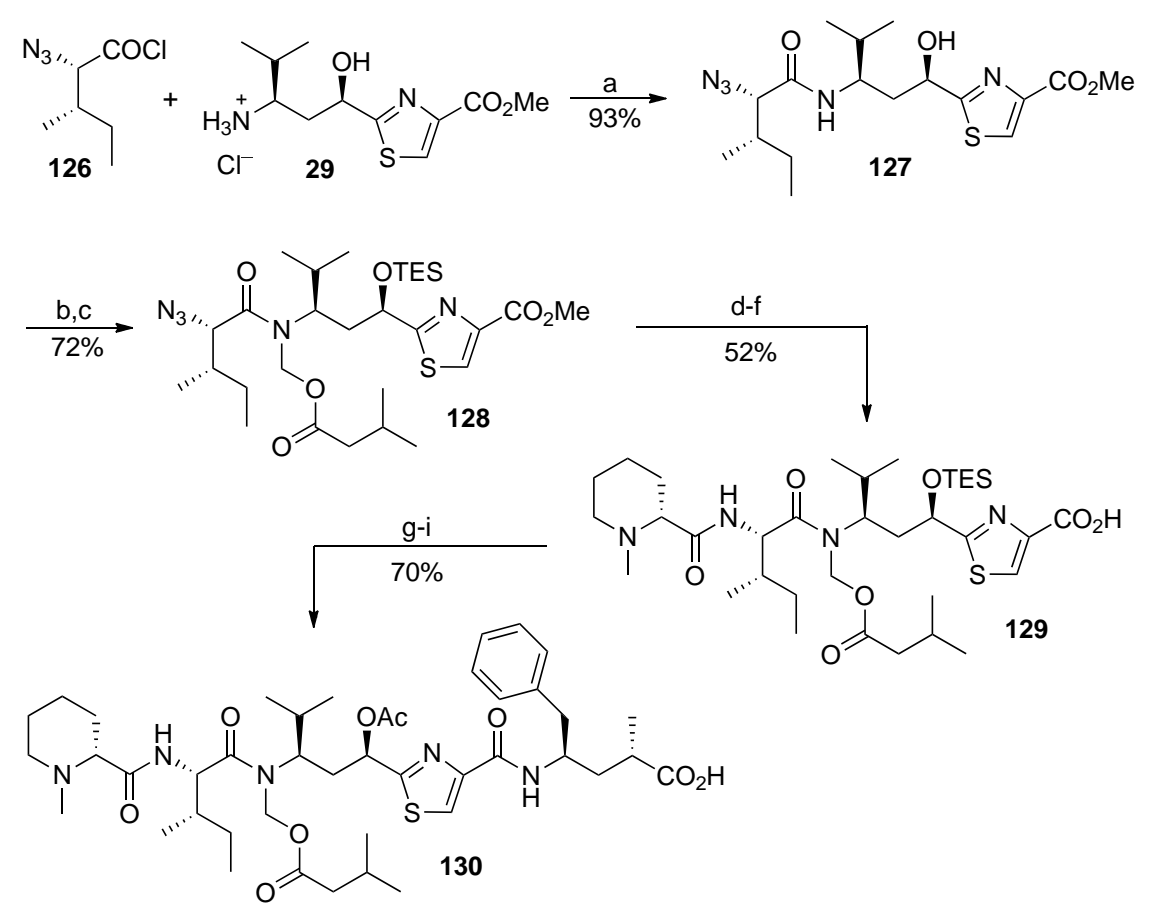

Scheme 29. Synthesis of tubulysin D (130) according to Ellman et al.: a) DIPEA, $\left.\mathrm{CH}_{2} \mathrm{Cl}_{2} ; \mathbf{b}\right)$ TESOTf, lutidine, $\left.\mathrm{CH}_{2} \mathrm{Cl}_{2} ; \mathbf{c}\right) 1$. $\mathrm{KHMDS}$, THF, $-45{ }^{\circ} \mathrm{C} ; 2 . i-\mathrm{BuCO}_{2} \mathrm{CH}_{2} \mathrm{Cl}$; d) $\left.\left.\left.\mathrm{Mep}-\mathrm{OC}_{6} \mathrm{~F}_{5}, \mathrm{H}_{2}, \mathrm{Pd} / \mathrm{C}, \mathrm{EtOAc} ; \mathbf{e}\right) \mathrm{AcOH} / \mathrm{THF} / \mathrm{H}_{2} \mathrm{O} ; \mathbf{f}\right) \mathrm{Me}_{3} \mathrm{SnOH}, \mathrm{Cl}\left(\mathrm{CH}_{2}\right)_{2} \mathrm{Cl}, 60{ }^{\circ} \mathrm{C} ; \mathbf{g}\right) \mathrm{C}_{6} \mathrm{~F}_{5} \mathrm{OH}, \mathrm{DIC}$, $\mathrm{CH}_{2} \mathrm{Cl}_{2}$; h) 84, DIPEA, DMF; i) 1 . Ac $\mathrm{Ac}_{2} \mathrm{O}$, pyridine; $2 . \mathrm{H}_{2} \mathrm{O}$ /dioxane.

sensitive $\mathrm{N}, \mathrm{O}$-acetal by using $\mathrm{Me}_{3} \mathrm{SnOH}$, according to a protocol described by Nicolaou et al. [58]. Activation of the free carboxylic acid as pentafluorophenyl ester and coupling with Tup 84 provided the required tetrapeptide which was finally $O$-acetylated to give tubulysin D (130).

An analogous strategy was used by Tamura et al. during their recent synthesis tubulysin epimers [47,59], as well as by Wessjohann et al. in their synthesis of tubulysin B [60].

\section{SYNTHESES OF TUBULYSIN DERIVATIVES}

If the tubulysins are treated with diluted acid, cyclization can occur giving rise to cyclo-tubulysins (131) (Scheme 30) $[47,60,61]$.
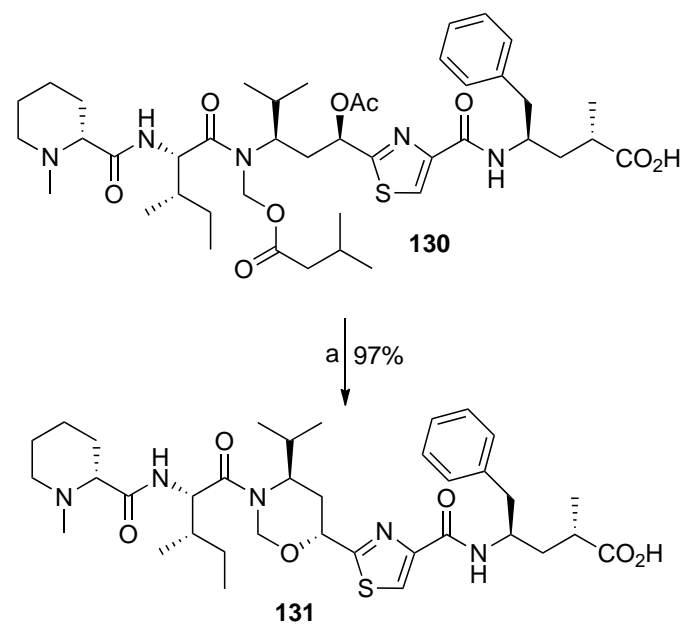

Scheme 30. Conversion of tubulysin D (130) into cyclo-tubulysin D (131): a) $1 \mathrm{~N} \mathrm{HCl}$, THF.
Vlahov et al. reported the interconversion of tubulysins (132) into a wide range of $N$-functionalized derivatives via a stabilized $N$-acyliminium ion (Scheme 31) [62]. Mixtures of different tubulysins (obtained by fermentation) were treated with trifluoroacetic acid, resulting in the cleavage of the different acyl side chains, forming the same $N$-acyl-iminium ion 133. Addition of several carboxylic acids allows the synthesis of new tubulysins 134, while the addition of alcohols and thiols gives rise to the corresponding $\mathrm{N}$-acyl- $\mathrm{N}, \mathrm{O}$-acetals 135 and $N$-acyl- $N, S$-thioacetals 136. Furthermore, the nitrogen of nitriles can also attack on the $N$-acyliminium ion in a Ritter reaction giving access to $N, N$ '-diacyl-aminal derivatives 137.

Wessjohann et al. described a very smart approach to highly potent tubulysin analogs named tubugis, in which the $\mathrm{N}, \mathrm{O}$-acetal moiety s replaced by a dipeptide element, which could easily be obtained in an Ugi reaction (Scheme 32) [63]. Two of the four components required were themselves produced by other multicomponent reactions (MCRs). Key step of the synthetic sequence was the Ugi reaction of dipeptide 138, silyl protected Tuv derivative 139, formaldehyde and a range of alkyl isocyanides to give the key fragment 140 in one step in acceptable yield. Cleavage of the protecting groups, peptide coupling with Tup-OMe 100 under standard conditions and acetylation of the secondary alcohol provided the tubugis $\mathbf{1 4 1}$ in high yield. Their biological activity is comparable to tubulysin A and in the subnanomolar range.

As a long $N$-side chain is not essential for good biological activity, it can be reduced to a $N$-methyl group without an extreme drop in activity. Wipf et al. reported the synthesis of $N$-desacyloxy tubulysin ( $N$-methyl tubulysin) in 2007 (Scheme 33) [40]. Deprotection of double protected 

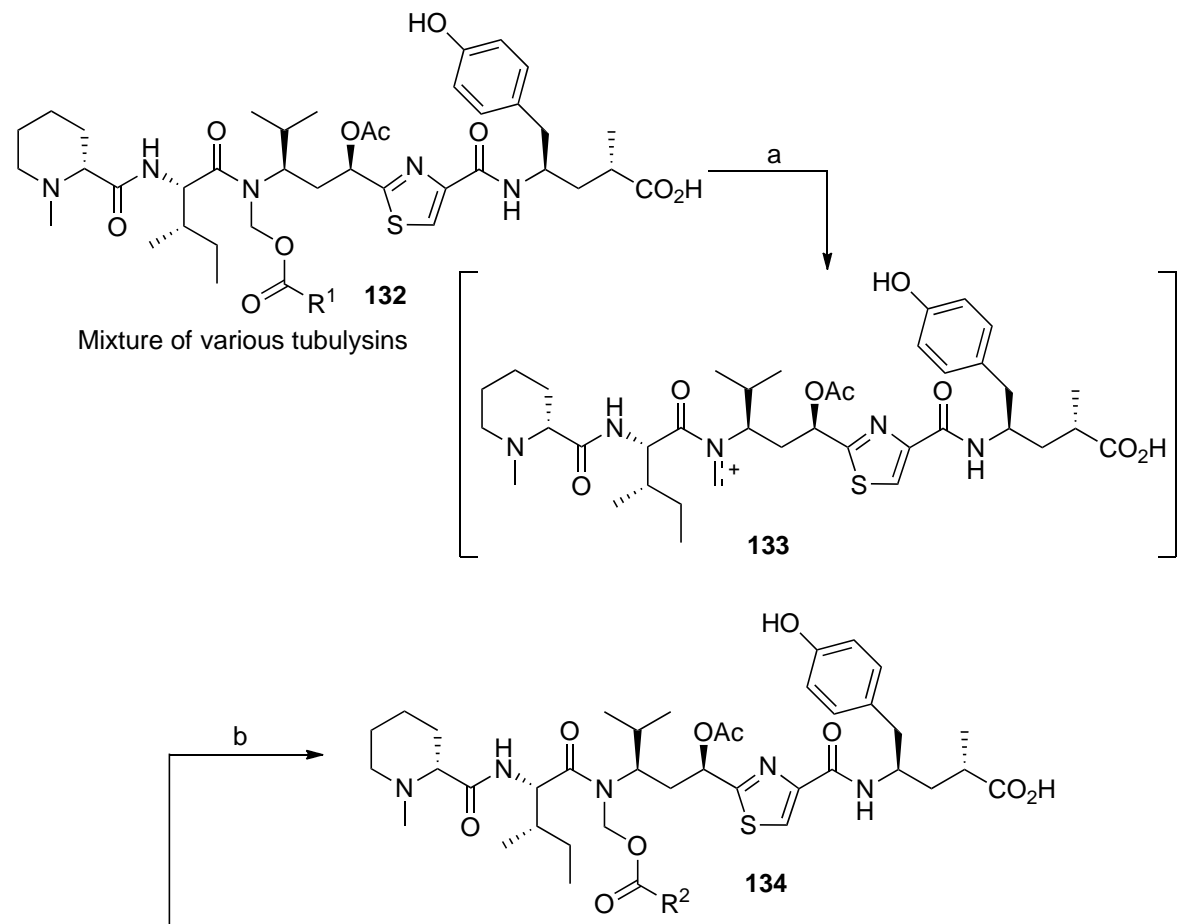

33
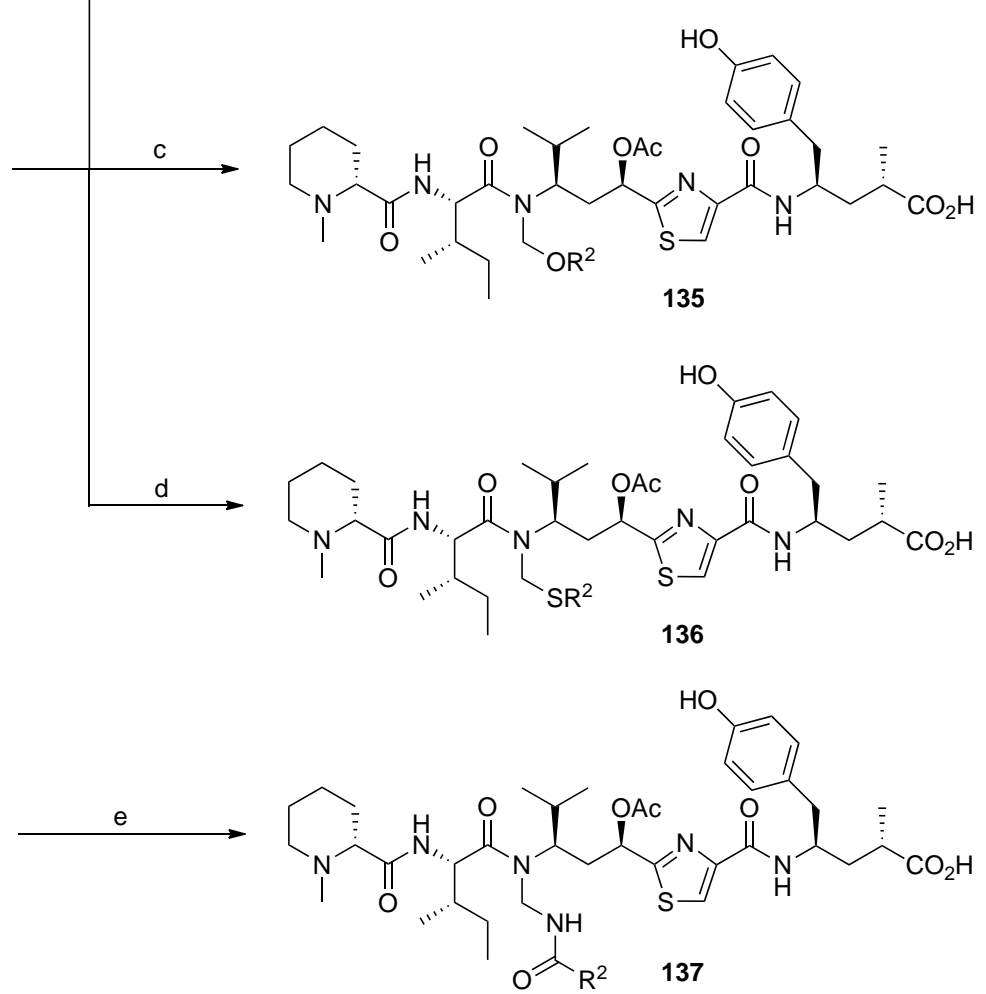

Scheme 31. Interconversion of tubulysins (132) according to Vlahov et al.: a) $\mathrm{TFA}, \mathrm{CH}_{2} \mathrm{Cl}_{2}$, rt; b) $\left.\mathrm{R}^{2} \mathrm{CO}_{2} \mathrm{H} ; \mathbf{c}\right) \mathrm{R}^{2} \mathrm{OH}$; d) $\mathrm{R}^{2} \mathrm{SH}$; e) $\mathrm{TFA}$, $\mathrm{H}_{2} \mathrm{SO}_{4}, \mathrm{R}^{2} \mathrm{CN}$.

Tup ester 142 and subsequent peptide coupling with Tuvderivative 33 provided dipeptide 143 in good yield. Attempts to couple this dipeptide to a protected lle-derivative was found to be not a trivial issue. Attempts with most coupling reagents failed or gave low yields due to the congested steric environment and the reduced reactivity of the $N$-methylated amine. The acyl fluoride 144 was the reagent of choice pro- viding the desired product $\mathbf{1 4 5}$ in up to $80 \%$ yield. After removing the Fmoc group, subsequent coupling with Mep and cleavage of the $C$-terminal allyl ester provided 146 in acceptable yield. The same approach was also used for the synthesis of other stereoisomers [26].

Ellman et al. described two independent approaches towards $N$-methyl analogs of the tubulysins (Scheme 34). 

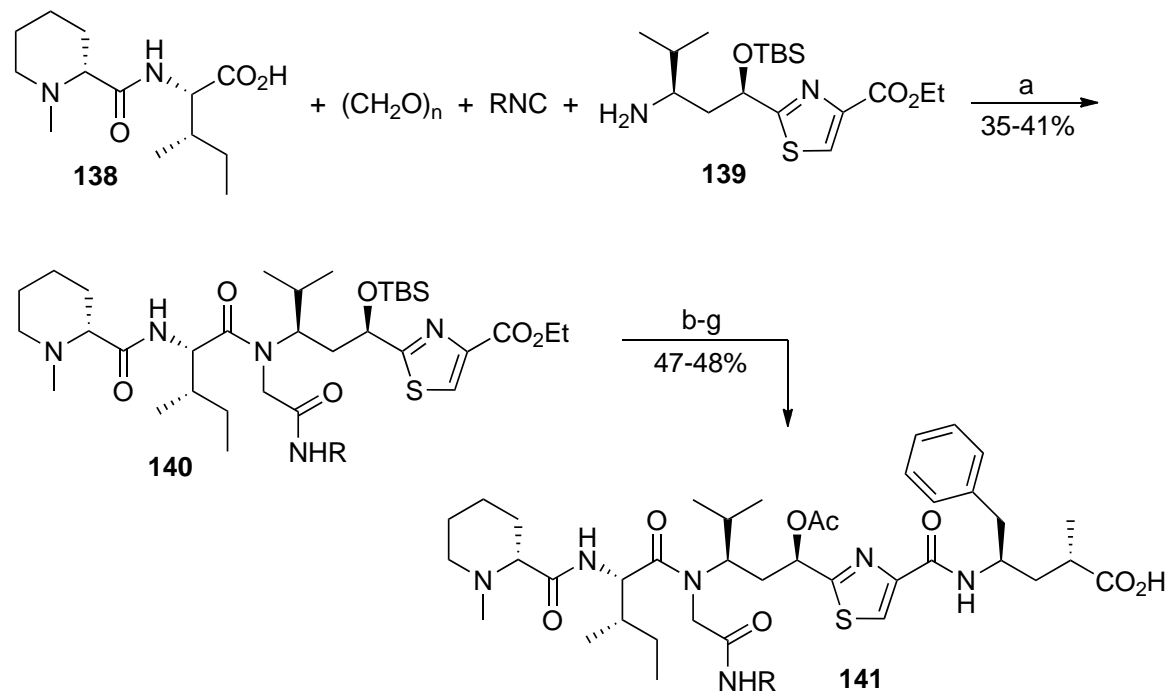

Scheme 32. Synthesis of tubugis $\mathbf{1 4 1}$ according to Wessjohann et al.: a) $\mathrm{MeOH}$; b) TFA, THF/ $\mathrm{H}_{2} \mathrm{O} ;$ c) $\mathrm{LiOH}, \mathrm{THF} / \mathrm{H}_{2} \mathrm{O}$; d) $\mathrm{C}_{6} \mathrm{~F}_{5} \mathrm{OH}, \mathrm{DIC}$, $\mathrm{CH}_{2} \mathrm{Cl}_{2}$; e) 100, DIPEA, DMF; f) $\left.\mathrm{LiOH}, \mathrm{THF} / \mathrm{H}_{2} \mathrm{O} ; \mathbf{g}\right) \mathrm{Ac}_{2} \mathrm{O} /$ pyridine.
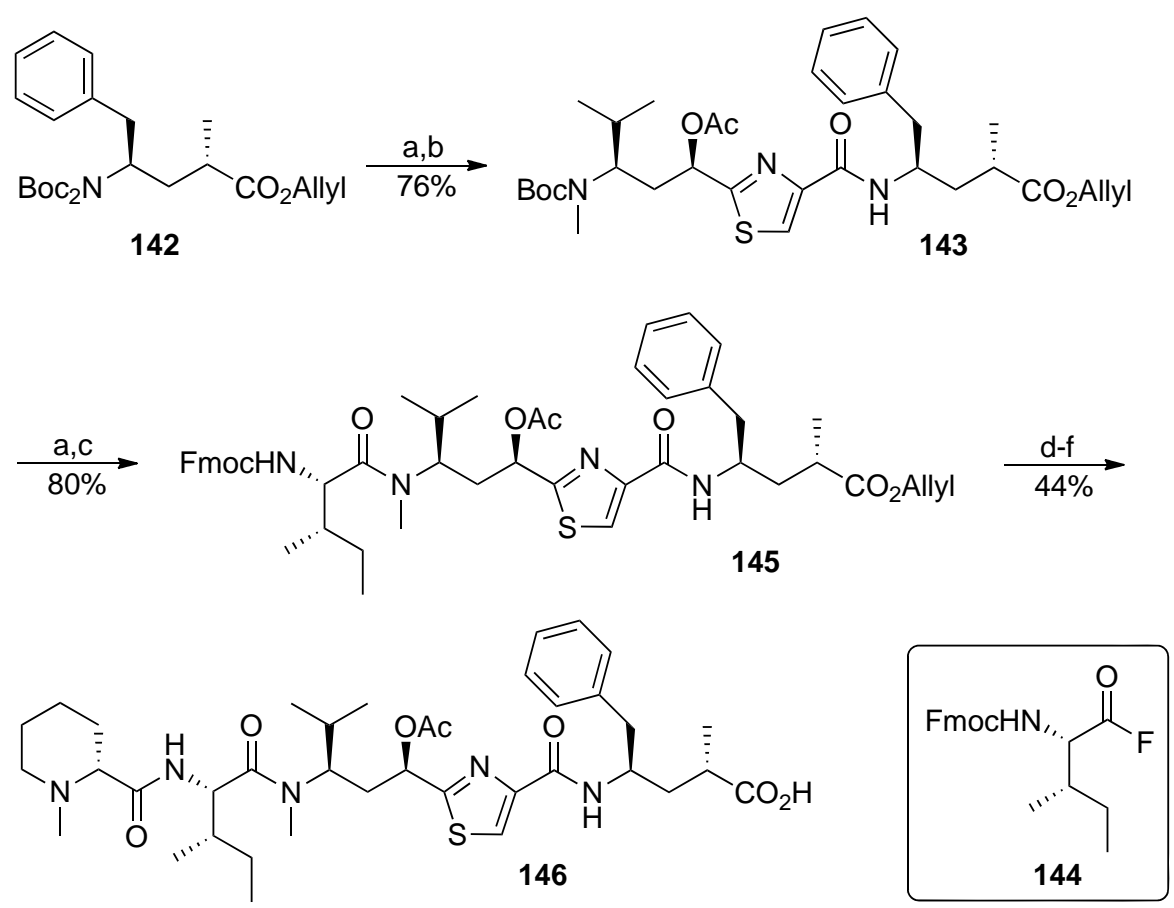

Scheme 33. Synthesis of $\mathrm{N}$-methyl tubulysin 146 according to Wipf et al.: a) TFA, $\left.\mathrm{CH}_{2} \mathrm{Cl}_{2} ; \mathbf{b}\right) 1 . i$ - BuOCOCl, $\mathrm{NEt}$; $2 . \mathbf{3 3},-20{ }^{\circ} \mathrm{C}$ to $\mathrm{rt}$; c) 144, DIPEA; d) $\mathrm{N}\left(\mathrm{CH}_{2} \mathrm{CH}_{2} \mathrm{NH}_{2}\right)_{3} ;$ e) $\left.\mathrm{Mep}-\mathrm{OC}_{6} \mathrm{~F}_{5} ; \mathbf{f}\right) \mathrm{Pd}\left(\mathrm{PPh}_{3}\right)_{4}$, dimedone.

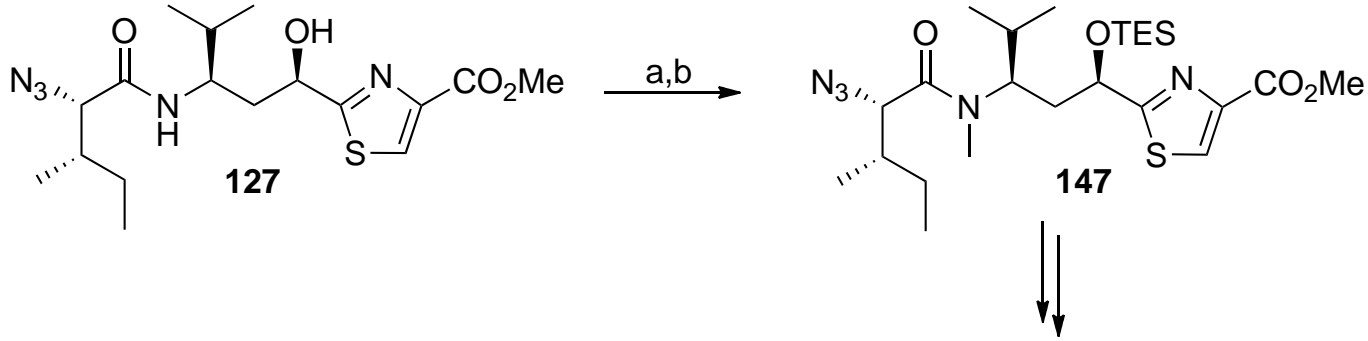


According to their synthesis of tubulysin D, azido dipeptide 127 was subjected to $N$-methylation and the methylated dipeptide 147 was further converted into 146 [23].

In a second approach, they started from $N$-sulfinylprotected Tuv-derivative 148 (Scheme 35) [23]. Simple heating of 148 with paraformaldehyde in toluene resulted in the formation of cyclic $N, O$-acetal 149 , which could be reduced with support-bound borohydride $\left(\mathrm{MP}-\mathrm{BH}_{3} \mathrm{CN}\right)$ to the required Tup-derivative 150. In analogy to the previous example, the subsequent peptide coupling was the most critical step. A wide range of coupling agents were investigated, but all failed to give the desired dipeptide. Instead, the corresponding ester 151 was formed preferentially. On heating, ester 151 undergoes an $\mathrm{O} \rightarrow \mathrm{N}$ acyl shift providing the desired dipeptide $\mathbf{1 5 2}$ in excellent yield. The final synthesis of 146 provided no further problems, and several derivatives have been prepared by this protocol [64].

Not only the acyl moiety from the $\mathrm{N}$-substituent can be removed without significant influence on activity, but also the acetoxy group in the Tuv fragment. Kazmaier et al. re- ported the synthesis of pretubulysin 154 (Scheme 36) which shows cytotoxicity towards a wide range of tumor cells in the low or subnanomolar range $[15,16]$. With the desacetoxy-Tuv-derivative 45, the peptide coupling (after Bocdeprotection) does not cause problems such as in the last examples, and especially good yields were obtained with BEP (2-Bromo-1-ethyl pyridinium tetrafluoroborate) as coupling reagent. Subsequent prolongation of the dipeptide $\mathbf{1 5 3}$ on both sides using standard peptide coupling reactions gave access to pretubulysin 154. Several derivatives have been prepared where the central thiazole ring has been replaced by other aromatic or heteroaromatic ring systems, but these derivatives were significantly less active $[18,25,65]$.

Also less active are tubulysins where the $N$-substituent is removed completely, such as in the tubulysins U and V. Several approaches towards these simplified analogs $\mathbf{1 5 8}$ have been reported, mainly based on standard peptide coupling protocols [20-22, 29, 30, 41, 52, 66]. A typical example leading to several modifications in the Tuv-fragment is shown in Scheme 37 [20].<smiles>CC(C)[C@H](C[C@@H](O)c1nc(C(=O)O)cs1)NS(=O)C(C)(C)C</smiles>

148<smiles>CCOC(=O)c1csc([C@@H]2C[C@H](C(C)C)N(S(=O)C(C)(C)C)CO2)n1</smiles>

149<smiles>CC[C@H](C)[C@H](NC(=O)OCc1csc([C@@H](C)C(=O)OCc2ccccc2)n1)C(C)C</smiles><smiles>CCOC(=O)c1csc([C@@H](O)C[C@H](C(C)C)N(C)C(=O)[C@@H](NC(=O)OCc2ccccc2)[C@@H](C)CC)n1</smiles>

Scheme 35. Synthesis of $N$-methyl tubulysin 146 according to Ellman et al.: a) $\left(\mathrm{CH}_{2} \mathrm{O}\right)_{\mathrm{n}}$, toluene, $\left.70{ }^{\circ} \mathrm{C} ; \mathbf{b}\right) \mathrm{MP}-\mathrm{BH}{ }_{3} \mathrm{CN}, \mathrm{MeCN} / \mathrm{EtOH}, \mathrm{HCl}$, dioxane, rt; c) Boc-IIe-OH, PS-DCCD, HOBt, $\mathrm{CH}_{2} \mathrm{Cl}_{2}$; d) toluene, $90{ }^{\circ} \mathrm{C}$; e) TFA, $\mathrm{CH}_{2} \mathrm{Cl}_{2}$; f) $\left.\mathrm{Mep}, \mathrm{PS}-\mathrm{DCCD}, \mathrm{HOBt}, \mathrm{CH}_{2} \mathrm{Cl}{ }_{2} ; \mathbf{g}\right) \mathrm{LiOH}$, $\mathrm{H}_{2} \mathrm{O}$ /dioxane; h) $\mathrm{Ac}_{2} \mathrm{O}$, pyridine; i) $\mathrm{C}_{6} \mathrm{~F}_{5} \mathrm{OH}$, DIC, $\left.\mathrm{CH}_{2} \mathrm{Cl}_{2} ; \mathbf{k}\right) \mathbf{8 4}$, DIPEA, DMF.<smiles>C=C[C@H](C)C(=O)N[C@@H](C(=O)N[C@H](C(=O)OCC)C(C)C)[C@@H](C)CC</smiles>

Scheme 36. Synthesis of pretubulysin 154 according to Kazmaier et al.: a) 1 . $\mathrm{HCl}$, dioxane, $0{ }^{\circ} \mathrm{C}$; b) Z-Ile, $\mathrm{BEP}, \mathrm{DIPEA}, \mathrm{CH}_{2} \mathrm{Cl}{ }_{2},-10{ }^{\circ} \mathrm{C}$. 


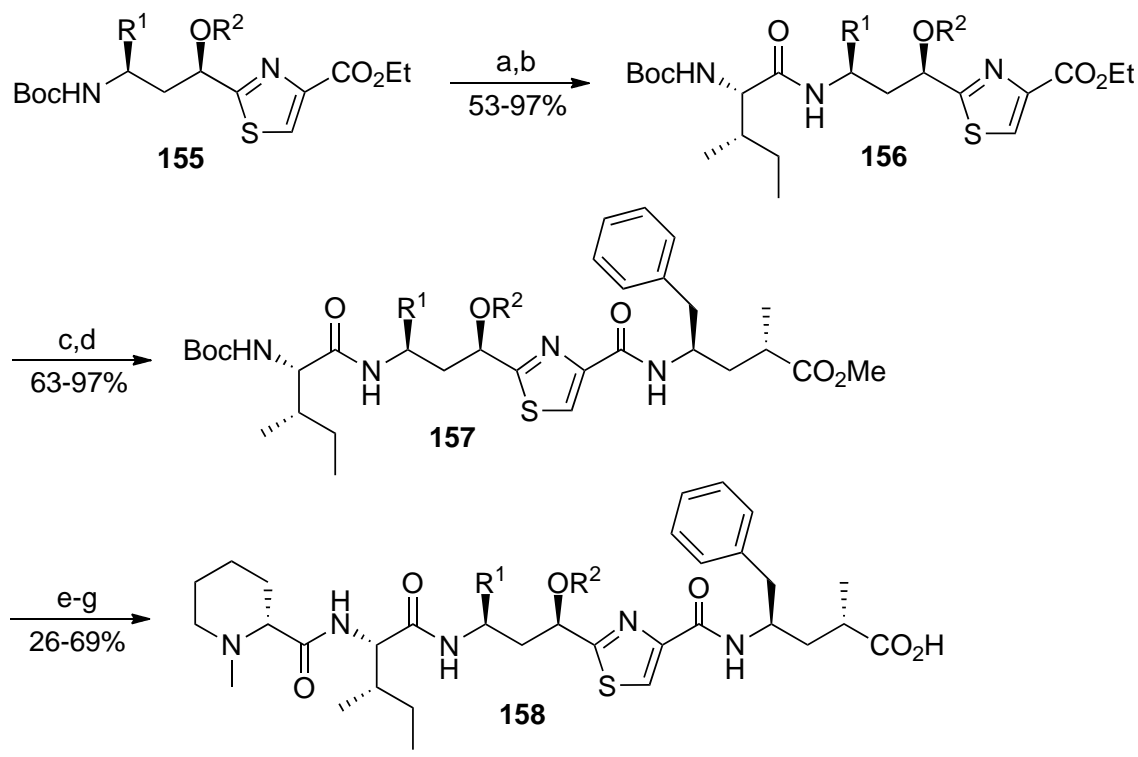

Scheme 37. Synthesis of simplified tubulysin derivatives 158 according to Sani and Zanda et al. a) TFA, $\mathrm{CH}_{2} \mathrm{Cl}_{2}, 0{ }^{\circ} \mathrm{C}$ to rt, $1 \mathrm{~h}$; b) $1 . \mathrm{HOBt}$, $\mathrm{EDC} \cdot \mathrm{HCl}$; 2. Boc-Ile-OH, DIPEA, $\mathrm{CH}_{2} \mathrm{Cl}_{2}, 0{ }^{\circ} \mathrm{C}$ to $\mathrm{rt}, 3 \mathrm{~h}$; c) $\mathrm{LiOH} \cdot \mathrm{H}_{2} \mathrm{O}, \mathrm{THF} / \mathrm{H}_{2} \mathrm{O}, 0{ }^{\circ} \mathrm{C}$ to rt, $\left.5 \mathrm{~h} ; \mathbf{d}\right) 1$. HOAt, $\mathrm{HATU} ; 2$. 100, NEt 3 , $\mathrm{CH}_{2} \mathrm{Cl}_{2}, 0{ }^{\circ} \mathrm{C}$ to rt, $3 \mathrm{~h}$; e) TFA, $\mathrm{CH}_{2} \mathrm{Cl}_{2}, 0{ }^{\circ} \mathrm{C}$ to rt, $1 \mathrm{~h}$; f) 1 . HOAt, HATU; 2 . Mep-OH, $\mathrm{NEt}_{3}, 0{ }^{\circ} \mathrm{C}$ to rt, $\left.3 \mathrm{~h} ; \mathbf{g}\right) 1 \mathrm{~N} \mathrm{LiOH}$, THF, $0{ }^{\circ} \mathrm{C}$ to rt, 2-3 days.

\section{CONCLUSIONS}

A wide range of synthetic protocols towards the synthesis of tubulysins, analogs and building blocks has been developed during the last years, allowing the synthesis of new derivatives in a straightforward manner. Structure-activity relationship (SAR) studies indicate that simplifications are tolerated in the $N$-side chain and on the Tuv motif, but at least an $N$-methyl group on the Tuv is required for good biological activity.

\section{CONFLICT OF INTEREST}

The author(s) confirm that this article content has no conflicts of interest.

\section{ACKNOWLEDGEMENT}

Financial support by the Deutsche Forschungsgemeinschaft (Ka 880/10-1) is gratefully acknowledged.

\section{REFERENCES}

[1] Sasse, F.; Steinmetz, H.; Heil, J.; Höfle, G.; Reichenbach, H. Tubulysins, new cytostatic peptides from myxobacteria acting on microtubuli. J. Antibiot. 2000, 53, 879-885.

[2] Steinmetz, H.; Glaser, N.; Herdtweck, E.; Sasse, F.; Reichenbach, H.; Höfle, G. Isolation, crystal and solution structure determination and biosynthesis of tubulysins - powerful inhibitors of tubulin polymerization from myxobacteria. Angew. Chem. 2004, 116, 49965000; (b) Isolation, crystal and solution structure determination, and biosynthesis of tubulysins--powerful inhibitors of tubulin polymerization from myxobacteria. Angew. Chem. Int. Ed. 2004, 43, 4888-4892.

[3] Sandmann, A.; Sasse, F.; Müller, R. Identification and analysis of the core biosynthetic machinery of tubulysin, a potent cytotoxin with potential anticancer activity. Chem. Biol. 2004, 11, 10711079.

[4] Chai, Y.; Shan, S.; Weissman, K. J.; Hu, S.; Zhang, Y.; Müller R. Heterologous expression and genetic engineering of the tubulysin biosynthetic gene cluster using Red/ET recombineering and inactivation mutagenesis. Chem. Biol. 2012, 19, 361-371.

[5] Chai, Y.; Pistorius, D.; Ullrich, A.; Weissman, K. J.; Kazmaier, U.; Müller R. Discovery of 23 natural tubulysins from Angiococcus disciformis An d48 and Cystobacter SBCb004. Chem. Biol. 2010, 17, 296-309.

[6] Kubicek, K.; Grimm, S. K.; Orts, J.; Sasse, F.; Carlomagno, T. The tubulin-bound structure of the antimitotic drug tubulysin. Angew. Chem. 2010, 122, 4919-4922; (b) The tubulin-bound structure of the antimitotic drug tubulysin. Angew. Chem. Int. Ed. 2010, 49, 4809-4812.

[7] Kaur, G.; Hollingshead, M.; Holbeck, S.; Schauer-Vukašinović, V.; Camalier, R. F.; Dömling, A.; Agarwal, S. Biological evaluation of tubulysin A - a potential anticancer and antiangiogenic natural product. Biochem. J. 2006, 396, 235-242.

[8] Khalil, M. W.; Sasse, F.; Lünsdorf, H.; Elnakady, Y. A.; Reichenbach, H. Mechanism of action of tubulysin, an antimitotic peptide from myxobacteria. ChemBioChem 2006, 7, 678-683.

[9] Neri, D.; Fossati, G.; Zanda, M. Efforts toward the total synthesis of tubulysins: new hopes for a more effective targeted drug delivery to tumors. ChemMedChem 2006, 1, 175-180.

[10] Kularatne, S. A.; Venkatesh, C.; Santhapuram, H.-K. R.; Wang, K.; Vaitilingam, B.; Henne, W. A.; Low, P. S. Synthesis and biological analysis of prostate-specific membrane antigen-targeted anticancer prodrugs. J. Med Chem. 2010, 53, 7767-7777.

[11] Leamon, C. P.; Reddy, J. A.; Vetzel, M.; Dorton, R.; Westrick, E.; Parker, N.; Wang, Y.; Vlahov, I. Folate targeting enables durable and specific antitumor responses from a therapeutically null tubulysin B analogue. Cancer Res 2008, 68, 9839-9844.

[12] Vlahov, I. R.; Wang, Y.; Kleindl, P. J.; Leamon, C. P. Design and regioselective synthesis of a new generation of targeted chemotherapeutics. Part II: Folic acid conjugates of tubulysins and their hydrazides. Bioorg. Med. Chem. Lett. 2008, 18, 4558-4561.

[13] Floyd, W. C., III; Datta, G. K.; Imamura, S.; Kieler-Ferguson, H. M.; Jerger, K.; Patterson, A. W.; Fox, Me. E.; Szoka, F. C.; Frechet, J. M. J.; Ellman, J. A. Chemotherapeutic evaluation of a synthetic tubulysin analogue-dendrimer conjugate in c26 tumor bearing mice. ChemMedChem 2011, 6, 49-53.

[14] Schluep, T.; Gunawan, P.; Ma, L.; Jensen, G. S.; Duringer, J.; Hinton, S.; Richter, W.; Hwang, J. Polymeric tubulysin-peptide nanoparticles with potent antitumor activity. Clin. Cancer Res. 2009, 15, 181-189. 
[15] Ullrich, A.; Chai, Y.; Pistorius, D.; Elnakady, Y. A.; Herrmann, J. E.; Weissmann, K. J.; Kazmaier U.; Müller, R. Pretubulysin, a potent and chemically accessible tubulysin precursor from Angiococcus disciformis. Angew. Chem. 2009, 121, 4486-4489; (b) Pretubulysin, a potent and chemically accessible tubulysin precursor from Angiococcus disciformis. Angew. Chem. Int. Ed. 2009, 48, $4422-4425$.

[16] Ullrich, A.; Herrmann, J.; Müller, R.; Kazmaier, U. Synthesis and biological evaluation of pretubulysin and derivatives. Eur. J. Org. Chem. 2009, 6367-6378.

[17] Herrmann, J.; Elnakady, Y. A.; Wiedmann, R. M.; Ullrich, A.; Rohde, M.; Kazmaier, U.; Vollmar, A. M.; Müller R.; Pretubulysin: from hypothetical biosynthetic intermediate to potential lead in tumor therapy. PLoS One, 2012, 7, e37416, 1-12.

[18] Rath, S.; Liebl, J.; Fürst, R.; Ullrich, A.; Burkhart, J. L.; Kazmaier, U.; Herrmann, J.; Müller, R.; Günther, M.; Schreiner, L.; Wagner, E.; Vollmar, A. M.; Zahler S. Anti-angiogenic effects of the tubulysin precursor pretubulysin and of simplified pretubulysin derivatives. Br. J. Pharmacol. 2012, 167, 1048-1061.

[19] Eirich, J.; Burkhart, J. L.; Ullrich, A.; Rudolf, G. C.; Vollmar, A. M.; Zahler, S.; Kazmaier, U.; Sieber, S. A. Pretubulysin derived probes as novel tools for monitoring the microtubule network via activity-based protein profiling and fluorescence microscopy. Mol. BioSyst., 2012, 8, 2067-2075.

[20] Shankar, S. P.; Jagodzinska, M.; Malpezzi, L.; Lazzari, P.; Manca, I.; Greig, I. R.; Sani, M.; Zanda, M. Synthesis and structure-activity relationship studies of novel tubulysin $U$ analogs - effect on cytotoxicity of structural variations in the tubuvaline fragment. Org. Biomol. Chem., 2013, 11, 2273-2287.

[21] Balasubramanian, R.; Raghavan, B.; Begaye, A.; Sackett, D. L.; Fecik, R. A. Total synthesis and biological evaluation of tubulysin $\mathrm{U}$, tubulysin V, and their analogs. J. Med. Chem. 2009, 52, 238240.

[22] Shankar S. P.; Sani, M.; Saunders, F. R.; Wallace, H. M.; Zanda M. Total synthesis and cytotoxicity evaluation of an oxazole analogue of tubulysin U. Synlett 2011, 1673-1676..

[23] Patterson, A. W.; Peltier, H. M.; Ellman, J. A. Expedient synthesis of $N$-methyl tubulysin analogs with high cytotoxicity. J. Org. Chem. 2008, 73, 4362-4369.

[24] Wang, Z.; McPherson, P. A.; Raccor, B. S.; Balachandran, R.; Zhu, G.; Day, B. W.; Vogt, A.; Wipf, P. Structure-activity and highcontent imaging analyses of novel tubulysins. Chem. Biol. Drug Des. 2007, 70, 75-86.

[25] Burkhart, J. L.; Müller, R.; Kazmaier, U. Syntheses and evaluation of simplified pretubulysin analogs. Eur. J. Org. Chem. 2011, 30503059 .

[26] Höfle, G.; Leibold, T.; Steinmetz, H. (GBF), DE 10008089, 2001 [Chem. Abstr. 2001, 135, 331296].

[27] Dömling, A.; Henkel, B.; Beck, B. (Morphochem), WO 2004005269, 2004 [Chem. Abstr. 2004, 140, 94054].

[28] Dömling, A.; Henkel, B.; Beck, B.; Illgen, K.; Sakamuri, S.; Menon S. (Morphochem), WO 2004005327, 2004 [Chem. Abstr. 2004, 140, 94300].

[29] Dömling, A.; Beck, B.; Eichelberger, U.; Sakamuri, S.; Menon, S.; Chen, Q.-Z.; Lu, Y.; Wessjohann, L. A. Total synthesis of tubulysin U and V. Angew. Chem. 2006, 118, 7393-7397; (b) Total synthesis of tubulysin U and V. Angew. Chem. Int. Ed. 2006, 45, 72357239.

[30] Wang, R.; Tian, P.; Lin, G. Stereoselective total synthesis of tubulysin V. Chin. J. Chem, 2013, 31, 40-48.

[31] Schöllkopf, U. Recent applications of $\alpha$-metalated isocyanides in organic synthesis. Angew. Chem. 1977, 89, 351-360; Angew. Chem. Int. Ed. Engl. 1977, 16, 339-348.

[32] Wipf, P.; Takada, T.; Rishel, M. J. Synthesis of the tubuvalinetubuphenylalanine (Tuv-Tup) fragment of tubulysin. Org. Lett. 2004, 6, 4057-4060.

[33] Wei, Z. Y.; Knaus, E. E. An efficient one-pot conversion of $\alpha$ amino acid esters to $\gamma$-amino- $\alpha, \beta$-unsaturated carboxylates. Org. Prep. Proc. Int. 1994, 26, 243-248.

[34] Li, H.; Jiang, X.; Ye, Y.; Fan, C.; Romoff, T.; Goodman, M. 3(Diethoxyphosphoryloxy)-1,2,3-benzotriazin-4(3H)-one (DEPBT): A new coupling reagent with remarkable resistance to racemization. Org. Lett. 1999, 1, 91-93.

[35] Lajoie, G.; Lépine, F.; Maziak, L.; Belleau, B. Facile regioselective formation of thiopeptide linkages from oligopeptides with new thionation reagents. Tetrahedron Lett. 1983, 24, 3815-3818.
[36] Schmidt, U.; Gleich, P.; Griesser, H.; Utz, R. Amino acids and peptides. 58. Synthesis of optically active 2-(1-hydroxyalkyl)thiazole-4-carboxylic acids and 2-(1-aminoalkyl)-thiazole-4carboxylic acids. Synthesis 1986, 992-998.

[37] Peltier, H. M.; McMahon, J. P.; Patterson, A. W.; Ellman, J. A. The total synthesis of tubulysin D. J. Am. Chem. Soc. 2006, 128, 1601816019.

[38] Inami, K.; Shiba, T. Total synthesis of antibiotic althiomycin. Bull. Chem. Soc. Jpn. 1985, 58, 352-360.

[39] Yang, X.; Dong, C.; Chen, J.; Liu, Q.; Han, B.; Zhang, Q.; Chen, Y. Design, synthesis, and biological activities of triazole tubulysin $\mathrm{V}$ analogue. Tetrahedron Lett. 2013, 54, 2986-2988.

[40] Wipf, P.; Wang, Z. Total Synthesis of $N^{14}$-Desacetoxytubulysin H. Org. Lett. 2007, 9, 1605-1607.

[41] Sani, M.; Fossati, G.; Huguenot, F.; Zanda, M. Total synthesis of tubulysins U and V. Angew. Chem. 2007, 119, 3596-3599; (b) Total synthesis of tubulysins U and V. Angew. Chem. Int. Ed. 2007, 46, 3526-3529.

[42] Corey, E. J.; Helal, C. J. Reduction of carbonyl compounds with chiral oxazaborolidine catalysts: A new paradigm for enantioselective catalysis and a powerful new synthetic method. Angew. Chem. 1998, 110, 2092-2118; (b) Reduction of Carbonyl Compounds with Chiral Oxazaborolidine Catalysts: A New Paradigm for Enantioselective Catalysis and a Powerful New Synthetic Method. Angew.Chem. Int. Ed. 1998, 37, 1986-2012.

[43] Raghavan, B.; Balasubramanian, R., Steele, J. C., Sackett, D. L.; Fecik, R. A. Cytotoxic simplified tubulysin analogs. J. Med. Chem. 2008, 51, 1530-1533.

[44] Chandrasekhar, S.; Mahipal, B.; Kavitha, M. Toward tubulysin: gram-scale synthesis of tubuvaline-tubuphenylalanine fragment. $J$. Org. Chem. 2009, 74, 9531-9534.

[45] Kim, B. M.; So, S. M.; Choi, H. J. A concise, modular synthesis of chiral peraza-macrocycles using chiral aziridines. Org. Lett. 2002, 4, 949-952.

[46] Shibue, T.; Hirai, T.; Okamoto, I.; Morita, N.; Masu, H.; Azumaya, I.; Tamura, O. Stereoselective synthesis of tubuvaline methyl ester and tubuphenylalanine, components of tubulysins, tubulin polymerization inhibitors. Tetrahedron Lett. 2009, 50, 3845-3848.

[47] Shibue, T.; Hirai, T.; Okamoto, I.; Morita, N.; Masu, H.; Azumaya, I.; Tamura, O. Total syntheses of tubulysins. Chem. Eur. J. 2010, $16,11678-11688$.

[48] Yang, X; Dong, C.; Chen, J.; Ding, Y.; Liu, Q.; Ma, X.; Zhang, Q.; Chen, Y. Total Synthesis of Tubulysin U and Its C-4 Epimer. Chem Asian J. 2013, 8, 1213-1222.

[49] Friestad, G. K.; Marié, J.-C.; Deveau, A. M. Stereoselective Mnmediated coupling of functionalized iodides and hydrazones: a synthetic entry to the tubulysin $\gamma$-amino acids. Org. Lett. 2004, 6 , 3249-3252.

[50] Enders, D.; Janeck, C. F.; Raabe, G.; Asymmetric $\beta$ aminoethylation of ketones and nitriles with tosylaziridines employing the SAMP-hydrazone method. Eur. J. Org. Chem. 2000, 3337-3345.

[51] Dömling, A.; Beck, B.; Eichelberger, U.; Sakamuri, S.; Menon, S.; Chen, Q.-Z.; Lu, Y.; Wessjohann, L. A. Total Synthesis of Tubulysin U and V (Corrigendum). Angew. Chem. 2007, 119, 23992400; (b) Total Synthesis of Tubulysin U and V (Corrigendum). Angew. Chem. Int. Ed. 2007, 46, 2347-2348.

[52] Balasubramanian, R.; Raghavan, B.; Steele, J. C.; Sackett, D. L.; Fecik, R. A. Tubulysin analogs incorporating desmethyl and dimethyl tubuphenylalanine derivatives. Bioorg. Med. Chem. Lett. 2008, 18, 2996-2999.

[53] Evans, D. A.; Bartroli, J.; Shih, T. L. Enantioselective aldol condensations. 2. Erythro-selective chiral aldol condensations via boron enolates. J. Am. Chem. Soc. 1981, 103, 2127-2129.

[54] Becker, D.; Kazmaier, U. Synthesis of tubuphenylalanines via Ireland-Claisen rearrangement. J. Org. Chem. 2013, 78, 59-65.

[55] Barton, D. H. R.; Hervé, Y.; Potier, P.; Thierry, J. Manipulation of the carboxyl groups of $\alpha$-amino-acids and peptides using radical chemistry based on esters of N-hydroxy-2-thiopyridone. Tetrahedron 1988, 44, 5479-5486.

[56] Marshall, J. A.; Garofalo, A. W. Oxidative cleavage of mono-, di-, and trisubstituted olefins to methyl esters through ozonolysis in methanolic NaOH. J. Org. Chem. 1993, 58, 3675-3680.

[57] Sasse, F.; Menche, D. Success in tubulysin D synthesis. Nat. Chem. Biol. 2007, 3, 87-89. 
[58] Nicolaou, K. C.; Estrada, A. A.; Zak, M.; Lee, S. H.; Safina, B. S. A mild and selective method for the hydrolysis of esters with trimethyltin hydroxide. Angew. Chem. 2005, 117, 1402-1406; (b) A mild and selective method for the hydrolysis of esters employing trimethyltin hydroxide, Angew. Chem. Int. Ed. 2005, 44, 13781382.

[59] Shibue, T.; Okamoto, I.; Morita, N.; Morita, H.; Hirasawa, Y.; Hosoya, T.; Tamura, O. Synthesis and biological evaluation of tubulysin D analogs related to stereoisomers of tubuvaline. Bioorg. Med. Chem. Lett. 2011, 21, 431-434.

[60] Pando, O.; Dörner, S.; Preusentanz, R.; Denkert, A.; Porzel, A.; Richter, W.; Wessjohann, L. First total synthesis of tubulysin B. Org. Lett. 2009, 11, 5567-5569.

[61] Höfle, G.; Glaser, N.; Leibold, T.; Karama, U.; Sasse, F.; Steinmetz H. Semisynthesis and degradation of the tubulin inhibitors epothilone and tubulysin. Pure Appl. Chem. 2003, 75, 167-178.

[62] Vlahov, I. R.; Wang, Y.; Vetzel, M.; Hahn, S.; Kleindl, P. J.; Reddy, J. A.; Leamon, C. P. Acid mediated formation of an $\mathrm{N}$ - acyliminium ion from tubulysins: a new methodology for the synthesis of natural tubulysins and their analogs. Bioorg. Med. Chem. Lett. 2011, 21, 6778-6781.

[63] Pando, O.; Stark, S.; Denkert, A.; Porzel, A.; Preusentanz, R.; Wessjohann L. A. The multiple multicomponent approach to natural product mimics: Tubugis, N-substituted anticancer peptides with picomolar activity. J. Am. Chem. Soc. 2011, 133, 7692-7695.

[64] Patterson, A. W.; Peltier, H. M.; Sasse, F.; Ellman, J. A. Design, Synthesis, and Biological Properties ofHighly Potent Tubulysin D Analogs. Chem. Eur. J. 2007, 13, 9534-9541.

[65] Burkhart, J. L.; Kazmaier, U. A straightforward click-approach towards pretubulysin-analogs. RSC Advances 2012, 2, 3785-3790.

[66] Shankar, S. P.; Jagodzinska, M.; Malpezzi, L.; Lazzari, P.; Manca, I.; Greig, I. R.; Sani, M.; Zanda, M. Synthesis and structureactivity relationship studies of novel tubulysin $\mathrm{U}$ analogs - effect on cytotoxicity of structural variations in the tubuvaline fragment. Org. Biomol. Chem. 2013, 11, 2273-2287.

(C) Kazmaier et al.; Licensee Bentham Open.

This is an open access article licensed under the terms of the Creative Commons Attribution Non-Commercial License (http://creativecommons.org/licenses/by-nc/3.0/) which permits unrestricted, non-commercial use, distribution and reproduction in any medium, provided the work is properly cited. 